\title{
ISO AND CODEX STANDARDS AND INTERNATIONAL TRADE LAW: WHAT GETS SAID IS NOT WHAT'S HEARD
}

\author{
FiLIPPo FontANelLi*
}

\begin{abstract}
This article challenges the rhetoric of hardening, according to which international standards become binding through WTO endorsement. The analysis of the system of presumptions set up in the Technical Barriers to Trade Agreement and Sanitary and Phyto-Sanitary Agreement reveals that international standards are actually used as a 'ceiling' rather than a 'floor' benchmark of protection, contrary to their original spirit. They represent a codified and agreed yardstick for least trade-restrictive measures, a minimum compromise between the regulatory regime and the trade litigation machinery. It follows that their nature - at least within the WTO system-is irreversibly distorted; they are treated as facts rather than as safety or quality devices.
\end{abstract}

\section{INTRODUCTION}

It is a commonplace that standards adopted by organizations such as the International Organization for Standardization ('ISO') and the Codex Alimentarius Commission ('Codex Commission') have undergone a regime shift, after having been absorbed into the regulatory frameworks of the Technical Barriers to Trade Agreement ('TBT') ${ }^{1}$ and the Sanitary and PhytoSanitary Agreement ('SPS'), ${ }^{2}$ two of the new-generation WTO treaties. This shift has attracted scholars' attention, particularly because many have seen in this interaction between the WTO and the standards bodies an instance of regulatory delegation. ${ }^{3}$ This has given rise to a diffuse trend of questioning the

* PhD, Sant'Anna School of Advanced Studies (Pisa); LLM Hauser Global Scholar, NYU 2010; Trainee clerk, International Court of Justice, 2010/2011. Email: <f.fontanelli@sssup.it>. Many thanks are due to Robert Howse, Fabrizio Cafaggi and two anonymous referees.

1 Agreement on Technical Barriers to Trade, Marrakesh Agreement Establishing the World Trade Organization, Annex 1A, opened for signature 15 April 1994, entered into force 1 January 1995.

2 Agreement on Sanitary and Phyto-Sanitary Measures, Marrakesh Agreement Establishing the World Trade Organization, Annex 1A opened for signature 15 April 1994, entered into force 1 January 1995.

3 T Buthe, 'The globalization of health and safety standards: delegation of regulatory authority in the SPS-Agreement of 1994 agreement establishing the World Trade Organization' (2008) 71 $\mathrm{L}$ and Contemporary Problems 219.

\section{CAMBridge JOURNALS}


origin, nature, legitimacy and accountability of the standards, based on the assumption that international standards, once incorporated into WTO rules, need to meet more stringent requirements, by virtue of their enhanced strength, reach and compulsory force. ${ }^{4}$

The main concern of this article is to examine this migration of standards onto the binding side of international trade law, and to ascertain whether in this process the standards stay the same, or their transplant into the regime of international trade entails a distortion of their normative nature. In other words, this article questions the commonly-held view that international standards endorsed by WTO norms acquire a (quasi) binding nature, by virtue of a process of 'hardening.'

Assuming that standards are adopted for a purpose, it is possible to talk about hardening only if these rules, besides enjoying a strengthened legal force, are also intended to serve the same purpose for which they were originally adopted. This analysis requires identifying the original purpose of the standards as well as their role in the WTO system, and a comparison between the two will clarify whether it is real hardening or something else. The identification of the purpose of international legal texts typically starts with a reading of the preambles of the relevant sources, but it does not always go much further. ${ }^{5}$ This exercise is often inconclusive; preambles both clarify the real purpose and pay lip-service to the non-sought ones.

This article aims at highlighting the real purpose of the standards by running a step-by-step analysis of the life of a rule, from conception to enforcement; arguably the description of the players and the stakes involved at each phase is more revealing than the declarations of intent. The analysis will be run

\footnotetext{
4 The literature on this issue is vast. See, for instance, H Horn and JHH Weiler, 'European Communities - Trade Description of Sardines: Textualism and its Discontent' in H Horn and PC Mavroidis (eds), The American Law Institute Report 2002 (CUP 2005) 251, 260; M Livermore, 'Authority and Legitimacy in Global Governance: Deliberation, Institutional Differentiation and the Codex Alimentarius' (2006) 81 New York UL Rev 766, 786-789; Y Bonzon, 'Institutionalizing Public Participation in WTO Decision Making: Some Conceptual Hurdles and Avenues' (2008) 11 J of Intl Economic L 751, 775ff; J Scott, 'International Trade and Environmental Governance: Relating Rules (and Standards) in the EU and the WTO' (2004) 15 Eur J of Intl L 307, 310; R Howse, 'A New Device for Creating International Legal Normativity: The WTO Technical Barriers to Trade Agreement and 'International Standards" in C Joerges and EU Petersmann (eds), Constitutionalism, Multilevel Trade Governance and Social Regulation (Hart Publishing 2006) 383, 391.

5 Vienna Convention on the Law of Treaties, adopted 23 May 1969, entered into force 27 January 1980, 115S UNTS 331 ('VCLT'), preambles are listed in art 31(2) among the elements useful for the analysis of the context of a treaty, and often international courts and tribunals use them as a shortcut to determine what the purpose of an instrument is. See eg C Schreuer, 'Diversity and Harmonization of Treaty Interpretation in Investment Arbitration' in M Fitzmaurice, O Elias, P Merkouris (eds), Treaty Interpretation and the Vienna Convention on the Law of Treaties: 30 Years (BRILL 2010) 129, 131 (referring to investment arbitration): 'The most frequent way to find a treaty's object and purpose was to look at the preamble.' With respect to the purpose of the European Convention of Human Rights see, in the same book, G Letsas, 'Intentionalism and the Interpretation of the ECHR', ibid., 257, 260, referring to the seminal Golder case (Golder v United Kingdom [1975] 1 EHRR 524).
}

\section{CAMBRIDGE JDURNALS}


twice: once upon voluntary standards in and of themselves, and once on their WTO avatars. The comparison will show that standards serve such a different purpose in the two regimes that talking of hardening is at least misleading. The article focuses on the ISO and Codex regulatory regimes since these two frameworks are by far the largest regulatory external 'tank' from which the WTO system draws its technical and phytosanitary standards and thus represent the optimal and most comprehensive subject for this research.

Part II thus offers an overview of the ISO and Codex regimes, accompanied by a breakdown of the respective roles of relevant stakeholders in the various phases of the regulating process. Part III considers the doctrine of the 'hardening' of voluntary standards due to the WTO renvoi, one that has gained authoritativeness over time but has arguably failed to prove convincing. In particular, the contention here is that even if a stretched interpretation of the relevant TBT and SPS provisions could justify the strengthening of standards through WTO endorsement, it is virtually impossible that an episode of violation in peius of the standards would actually be litigated before the DSB. In principle, the use of the standards as a ceiling for national regulations is at odds with the typical function of standards originated outside the trade arena, which is the setting of minimum levels of protection.

In Part IV the implications of WTO endorsement of international standards described in Part II are revisited, with some reflections on other elements revealing the nature of this regime shift ${ }^{6}$ (the role of third party beneficiaries or affected third parties, the concept of due diligence defence). A few general remarks will conclude (Part V).

\section{AN APPRAISAL OF THE STANDARDIZATION REGIMES}

Before discussing the consequences arising from WTO endorsement, it is first necessary to provide a brief description of the ISO and Codex regimes, explaining their historical origin, their nature (in terms of the public-private divide), their purpose and their structure (section A). Then, using the ANIME method developed by Abbott and Snidal for the analysis of regulatory processes, the various actors involved at each step of the Codex and ISO regulatory processes are identified (section B).

\footnotetext{
6 See LR Helfer, 'Regime Shifting in the International Intellectual Property System' (2009) 7 Perspectives on Politics 39; 'Regime Shifting: The TRIPs Agreement and New Dynamics of International Intellectual Property Lawmaking' (2004) 29 Yale J of Intl L 1. Although some features of Helfer's model apply to the present study (eg the consequential importance of the differences between the regimes, with respect to the binding force of their norms or the design of their law-making procedures), in this study the regime-shift expression applies to the norms rather than to the actors, and merely depicts the migration of international standards into the realm of international trade law.
}

\section{CAMBRIDGE JOURNALS}




\section{A. Regime Description}

\section{Codex Alimentarius}

The Codex Commission ('CC') ${ }^{7}$ was established in the early 1960 s as an intergovernmental body within the UN system, ${ }^{8}$ and its competence covers all matters pertaining to the implementation of the Joint FAO/WHO Food Standards Programme, consisting mainly in the coordination of existing food standards and the drafting, circulation, adoption and publication of new ones. Its general purpose, which should be reflected in its standard-setting activity, is that of 'protecting the health of the consumers and ensuring fair practices in the food trade'. 9 Membership of the Commission is open to all States that are members of either the $\mathrm{FAO}$ or the $\mathrm{WHO},{ }^{10}$ and its internal structure reflects that of a typical international intergovernmental organization articulated under an associational model. ${ }^{11}$

The standard-setting activity ${ }^{12}$ is run mainly by the $\mathrm{CC}$, and is triggered by proposals coming from national governments or subsidiary committees. The Commission has a pivotal role and decides the priority according to which proposals for standards are to be implemented, and which subsidiary committees must draft the standards. The draft standards are then circulated among members for comment, and submitted to the $\mathrm{CC}$ for approval, before being published and included in the Codex Alimentarius. ${ }^{13}$

Codex standards are not binding on Member States, ${ }^{14}$ who are nevertheless encouraged, as a general practice, to accept them voluntarily and to enact

${ }^{7}$ For a more detailed description of the Codex Commission and its activity, see RA Pereira, 'Why Would International Administrative Activity Be Any Less Legitimate? A Study of the Codex Alimentarius Commission' (2008) 9 German LJ 1693, 1695ff.

${ }^{8}$ The Conference of Food and Agriculture Organisation (FAO), in 1961, and the World Health Organization (WHO) Assembly, in 1963, adopted the resolutions establishing the Codex Commission. They also adopted the Statutes and Rules of Procedure for the Commission.

${ }_{9}$ See art 1 of the Codex Statutes, available at $<$ http://www.fao.org/DOCREP/005/Y2200E/ y2200e $02 . h t m>$.

10 See ibid art 2

${ }^{11}$ Under the Rules of Procedure, the Commission has one chairperson and three vicechairpersons to be elected at each annual session, a secretary appointed by the FAO and the WHO, and some regional Coordinators (Rule V). The chairpersons, together with seven member representatives, form the Executive Committee, which shall report to the Commission (Rule VI). The Rules of the Commission can be amended with the vote of two-thirds of the members (Rule XIII). See the full text of the Rules at <http://www.fao.org/DOCREP/005/Y2200E/y2200e03. htm\#TopOfPage $>$.

12 The full procedures for the adoption of standards are encompassed in the Procedures for the Elaboration of Codex Standards and Related Texts adopted by the Commission, available at <http://www.fao.org/DOCREP/005/Y2200E/y2200e04.htm\#TopOfPage>.

${ }^{13}$ For a recent and comprehensive description of the process, see S Henson and J Humphrey, The Impacts of Private Food Safety Standards on the Food Chain and on Public Standard-Setting Processes (Paper for FAO/WHO May 2009) 24ff.

${ }^{14}$ See the FAQ page of the Codex website <http://www.codexalimentarius.net/web/faq_gen. jsp\#G11>: 'General Question 11: Are Codex Standards mandatory? Answer: Codex texts are voluntary and non-binding ....'

\section{CAMBRIDGE JULRNALS}


domestic rules incorporating them. The General Principles of the Codex ${ }^{15}$ provide for three kinds of acceptance-full acceptance, acceptance with specific deviations, and free distribution-graduated according to the degree of force accorded to the standards in the domestic market. ${ }^{16}$ This voluntary nature of the standards is very important for the present analysis, because it assimilates Codex standards to other forms of private regulation and represents the necessary precondition for the 'hardening rhetoric' recalled above. It also justifies the choice of the Codex as an object of this study, despite the public aspects reflected in its membership and structure. ${ }^{17}$

\section{ISO}

The International Standard Organization, in turn, is a prima facie hybrid actor. It is a federation of national standard-setting bodies, which can differ markedly in terms of structure; whereas some among them are governmental agencies (for instance the French Association Française de Normalisation 'AFNOR'), others are private bodies (such as the British Standard Association, or the US American National Standards Institute, a private organization composed of private members and officials of federal agencies). ${ }^{18}$ ISO was established in 1947 under the form of an association governed by Swiss corporate law. ISO's primary stakeholder is the industry sector, which provides expertise both to governmental and private domestic bodies. ${ }^{19}$

${ }^{15}$ Available at $<$ http://www.fao.org/DOCREP/005/Y2200E/y2200e05.htm\#TopOfPage > .

${ }^{16}$ For instance, full acceptance of a standard implies that food not conforming therewith shall not be distributed under the name or description laid down in the standard (see Principle 4A.i).

17 According to the taxonomy of GK Hadfield, 'The Public and the Private in the Provision of Law for Global Transactions' in V Gessner (ed), Contractual Certainty in International Trade: Empirical Studies and Theoretical Debates on Institutional Support for Global Economic Exchanges (Hart Publishing 2009) 238, Codex standards would rank as public under some criteria, but they would still have a 'private ordering' aspect, since 'legal obligations based in private ordering derive exclusively from the intent and consent of the obligated party to be bound.' (240). See also D Vogel, 'Private Global Business Regulation' (2008) 11 Annual Rev of Political Science 261, 265 (regarding ISO regulations). Similarly, F Cafaggi, Product Safety, Private Standard Setting and Information Networks (Working Paper 2008/17 EUI 2008) 10, refers to technical standards as 'privately produced' when compliance is voluntary. For a distinction between private regulation, co-regulation and ex-post recognized self-regulation see F Cafaggi, Rethinking Private Regulation in the European Regulatory Space (Working Paper 2006/13 EUI 2006). Not surprisingly, as Pereira (n 7) notes, there is no consensus regarding the nature of the Codex. See B Kingsbury, N Krisch and RB Stewart, 'The Emergence of Global Administrative Law' (2005) 68 $\mathrm{L}$ and Contemporary Problems 15 (CC is a hybrid body); A Herwig, 'Transnational Governance Regimes for Foods Derived from Bio-Technology and their Legitimacy' in C Joerges, I-J Sand and Gunther Teubner (eds), Transnational Governance and Constitutionalism (Hart Publishing 2004) 199, 204; J Pauwelyn, 'Non-Traditional Patterns of Global Regulation: Is the WTO 'Missing the Boat'?' in Joerges and Petersmann (n 4) 199, 208-215(CC is essentially a public body).

${ }^{18}$ Members can apply for full membership or for correspondent membership, which entitles them to an observer status during the sessions of the Technical Committees.

19 The mixed membership, the associational model and the voluntary nature of the standards adopted make it possible to consider ISO a hybrid regime, or even a private one. See for instance

\section{CAMBridge JOURNALS}


The purpose of the ISO is to adopt global technical standards in all fields except for electronic engineering and telecommunication. ISO's jurisdiction is expanding, and over time it has adopted standards relating to environmental protection (the ISO 14000 series) and corporate social responsibility (the ISO 26000 series, launched in 2010). ${ }^{20}$ Only ISO members are involved in decision making and participate in every phase of the norm-setting procedure (receiving drafts, providing comments, voting for the adoption); non-governmental organizations (NGOs), in contrast, can only serve as liaison organizations, ${ }^{21}$ a status that allows them to observe and comment upon the work of the Committees. The restrictive nature of the procedure continues after the adoption of the standards, which are not freely accessible to the general public, but are available to purchase. ${ }^{22}$

The ISO standard-setting process is generally less open and transparent than that of the Codex, and whereas Codex standards are primarily intended to serve at least as a model for national binding regulation, ISO's primary mission is the adoption of voluntary standards and it is for the Member States to decide how to implement them domestically. However, the certification method (see below) makes ISO standards effective and appealing to private firms regardless of specific national implementation or incorporation into State law.

\section{B. ANIME}

In order to understand a regulatory regime more fully, it is useful to divide the regulatory process into phases, and to identify the subjects that are involved in, or responsible for, each phase. In this section we adopt the 'ANIME' method, which is a step-by-step analysis of the regulatory process. based on the following phases: Agenda-setting, Negotiation and adoption, Implementation, Monitoring and Enforcement. ${ }^{23}$ This ANIME method is employed here to

J Clapp, 'The Privatization of Global Environmental Governance: ISO 14000 and the Developing World' (1998) 4 Global Governance 295, 301 (ISO is a hybrid body); F Cafaggi, The Architecture of Transnational Private Regulation (EUI Working Paper 2011/12) 9 (ISO is a private regulator).

${ }^{20}$ For a full account of standardization procedures, see the ISO/IEC Directives 'Procedures for Technical Works', available at $<\mathrm{http}: / / \mathrm{www}$.iso.org/directives $>$.

${ }^{21}$ E Shamir-Borer, The Evolution of Administrative Law-Type Principles, Mechanisms and Practices in the International Organization for Standardization (ISO) (Paper NYU Global Hauser Colloquim 2006) 21.

${ }^{22}$ For a limited set of matters, typically linked with environmental protection and corporate social responsibility, the procedure has been gradually opened to include other stakeholders, see N Roht-Arriaza, 'Soft Law' in a 'Hybrid' organization: The International Organization for Standardization' in D Shelton (ed), Commitment and Compliance: The Role of Non-Binding Norms in the International Legal System (OUP 2000) 265.

${ }^{23}$ See KW Abbott and D Snidal, 'The Governance Triangle: Regulatory Standards Institution and the Shadow of the State' in W Mattli and N Woods (eds), The Politis of Global Regulation (Princeton University Press 2009) 44, 63.

\section{CAMBRIDGE JDURNALS}


illuminate the role of different actors in the Codex and ISO standardization processes.

\section{Codex Alimentarius}

\section{a) Agenda-Setting}

The Rules of Procedure are clear in endowing any member of the Commission, along with the Directors-General of the FAO and WHO, with the power to propose the inclusion of an item in the agenda for a session of the Commission. ${ }^{24}$ The proposed agenda is then voted by the Commission. ${ }^{25}$

\section{b) Negotiation and Adoption}

The process of drafting and adoption is almost entirely internal to the Commission and the members. The FAO and WHO can provide guidelines on certain particular matters ${ }^{26}$ and, in the limited case of dairy products, the International Dairy Federation (made up of representatives of the national dairy industries) can issue recommendations to the drafters.

An intense session of comments from members and interested international organizations precedes the final adoption by the Commission. International non-governmental organizations are allowed to take part in every stage of the drafting procedure, except for the adoption one. ${ }^{27}$

\section{c) Implementation}

It is important to specify which substantial purpose the Codex standards pursue, in order to examine the implementation phase, but it is not an easy task. Several aims are listed among those belonging to the Commission, and each of them would correspond to a different implementation stage, and a different responsible actor. For instance, if the very purpose of the standards were the

24 See Rule V of the Rules of Procedure, (n 11). $\quad 25$ See ibid, Rule VI.

26 Namely, when the standards incorporate a maximum limit for residues of pesticide or veterinary drugs, see Procedures for the Elaboration (n 12), Part 1, Step 2.

27 See the Principles Concerning the Participation of International Non-Governmental Organizations in the Work of the Codex Alimentarius Commission, available at $<\mathrm{http}: / / \mathrm{www}$. fao.org/DOCREP/005/Y2200E/y2200e09.htm\#TopOfPage $>$. Such principles establish an accreditation procedure, through which organizations having a particular connection with the matters covered by the standards (in terms of expertise, competence, aims or subject-field) can apply for the status of observers. See also the report International Non-governmental Organizations in Observer Status with the Codex Alimentarius Commission, Report by the Secretariat (CAC/30 $\mathrm{INF} / 2$ ), available at $<\mathrm{ftp}: / / \mathrm{ftp}$.fao.org/Codex/CAC/CAC30/if30_02e.pdf $>$. It must be noted that, according to official reports, industry-related NGOs hugely outnumber consumers' associations, see Pereira (n 7) 1709. See also, on participatory issues in the Codex, T Huller and ML Maier, 'Fixing the Codex?: Global Food-Safety Governance under Review' in Joerges and Petersmann (n 4) 267, $271 \mathrm{ff}$ (acknowledging that the large majority of observer NGOs belong to the producers or traders' community); Livermore (n 4) 783-786.

\section{CAMBRIDGE JOURNALS}


harmonization of international food standards, implementation would occur through the adoption of national norms incorporating them, the implementing subjects being the domestic rule-makers. Instead, if the prevailing interest were the fairness of international trade in foods, the implementation task would perhaps be carried out by trade authorities granting equal market access to food abiding by the same standards. Although the second hypothesis will be explored below, Part II will take a more traditional position as regards implementation for the purpose of the ANIME breakdown; implementation is typically reflected in compliance with the standards, and is therefore carried out by the subjects producing, processing, distributing and selling the food, that is, the companies. ${ }^{28}$

\section{d) Monitoring}

Several actors can be expected to play a monitoring role in connection with Codex standards, reacting to cases of non-compliance. Consumers are the most obvious candidates, as they are the direct beneficiaries of standards compliance and, conversely, the most affected in case of non-compliance. Retailers and distributors may adopt policies requiring compliance by Codex standards, hence bearing an interest to monitor the actual respect thereof along the supply chain. The Codex Commission does not perform directly certification activities, but encourages Member States to set up a system of certification run by official bodies or officially recognized bodies. ${ }^{29}$

\section{e) Enforcing}

Non-compliance issues raised through monitoring can be considered and enforced in different venues. Courts may adjudicate disputes arising from consumers' claims alleging the violation of standards (either under tort or contract law). ${ }^{30}$ Retailers and distributors can terminate their business relationship with producers and suppliers for non-compliance with the standards. Third-party certifiers may threaten the withdrawal of, or deny the award of, certification. State authorities are empowered to regulate (and deny) market access to food that is produced or processed in violation of standards (that is, they are not bound to apply the 'safe haven' provisions of the international

\footnotetext{
28 See Henson and Humphrey (n 13) 15. On the 'mixity' of the Codex's original purpose see Huller and Maier (n 27) 269: 'If several potentially conflicting goals are built into the mandate of an individual organization, as in the case of Codex, conceptualizing problem-solving capacity is [a] daunting task.' See also Buthe (n 3) 223.

${ }^{29}$ See the Principles for Food Import and Export Inspection and Certification Cac/G1 20-1995, adopted by the Codex Alimentarius Commission at its $21^{\text {st }}$ Session, 1995, available at $<$ http:// www.fao.org/docrep/009/y6396e/Y6396E01.htm\#ch1>.

30 See A G Chan, 'Qs-9000 and Its Legal Implications' (1999) 64 J of Air L and Commerce 1123,1147 , describing plaintiffs' use of court claims founded on violations of voluntary standards.
}

\section{CAMBRIDGE JOURNALS}


trade regime, a concept that shall be considered infra). Independent authorities active in the field of food safety can assess non-complying companies where the standards have been incorporated into applicable domestic regulations.

\section{ISO}

\section{a) Agenda-Setting}

The impulse triggering a standard-drafting session comes from the industry sector, which communicates its needs to the respective member(s). After consideration, and assessment of the potential interests of other industry sectors and stakeholders, a member submits the proposal to the relevant ISO organ, to initiate the drafting process. ${ }^{31}$ Technical Committees and SubCommittees examine the proposal, expertise-based Working Groups define technical specifications, and then a consensus (or at least a two-thirds majority) is required among members to pass to the next phase.

\section{b) Negotiation and Adoption}

The process is run by the members, grouped into Technical Committees, and supported by professional experts. Members are free to decide their structure and internal membership, therefore there is not a common model accounting for the identification of the actors taking part in the drafting phase. However, it is fair to say that national standard bodies are dominated by government members and industry representatives, ${ }^{32}$ with consumers' organizations having relatively little voice, despite all the calls for inclusiveness that the ISO itself has made. ${ }^{33}$ Experts are also involved throughout, although it would be difficult to state clearly whose interests they are supposed or seek to represent within the process. Overall, consumers are under-represented, and the industry community (which can even submit self-prepared technical standards to obtain

31 E Shamir-Borer, The Evolution of Administrative-Law Norms and Mechanisms in the International Organization for Standardization (ISO) (Paper GAL Conference-Viterbo 2006), see, generally, ISO/IEC Directives (n 20).

Industries are encouraged to take part in the decision-making process, see, for instance, $\mathrm{HJ}$ de Vries, 'Standards for business - How companies benefit from participation in international standards setting' in International Standardization as a strategic tool (International Electronical Commission 2006) 130.

33 See the relevant clauses of the ISO Code of Ethics, (2004) $<$ http://www.iso.org/iso/en/ aboutiso/ethics/ethics.html $>$, and the ISO document 'The Consumer and Standards: Guidance and Principles for Consumer Participation in Standards Development', available at $<$ http://www.iso. org/iso/standardsandconsumer.pdf $>$. For an extensive discussion of participatory issues, see Shamir-Borer (n 21); H Zúñiga Schroder, 'Definition of the Concept 'International Standard' in the TBT Agreement' (2009) $43 \mathrm{~J}$ of World Trade 1223, 1233ff; BJ Farquhar, 'Governance in the International Organization for standardization (ISO) and the International Electrotechnical Commission (IEC)' in K Dawar (ed), Decision Making in the Global Market: Trade, Standards and the Consumer (Consumers International 2005) 45, 60-62.

\section{CAMBRIDGE JDURNALS}


ISO recognition ${ }^{34}$ ) is leading the decision-making process, either directly or through the government representatives. ${ }^{35}$

\section{c) Implementation}

The same caveat made for the Codex applies here. ${ }^{36}$ However, we adhere to a traditional approach, and acknowledge that the companies (the industry sector) are the subjects complying with the standards, and implementing them (after having bought them from ISO). We also assume that standards are not incorporated in national regulations, which would make them binding, and would alter profoundly the following monitoring and enforcement phases.

\section{d) Monitoring}

ISO standards have a prominent market-related function. They work as a signal of quality for consumers and retailers (who are relatively uninterested in their trade-facilitating function). Certification, like compliance, is a matter of voluntariness; companies can self-assess ISO performances, or resort to third party certifiers, to improve their credibility record. ${ }^{37}$ ISO does not carry out any conformity assessment activity, nor does it perform certification duties; ${ }^{38}$ national standardization bodies are responsible for certifying compliance directly or by accrediting other certification bodies.

\footnotetext{
34 JK Winn, 'Globalization and Standards: the Logic of Two-Level Games' (2009) 5 I/S: J of L and Policy for the Information Society 185, 210.

${ }^{35} \mathrm{~N}$ Krisch, 'The Emerging Global Administrative Law' (2006) 17 European Journal International Law 265. See also S Baird, 'The Government at the Standards Bazaar' (2007) 18 Stanford L and Policy Rev 35, arguing for government's non-intervention in the setting of information technology standards.

${ }^{36}$ In the case of ISO, where standards are a product on sale, the confusion is further aggravated by marketing strategies: on the ISO website, standards are claimed to pursue a large number of purposes, ranging from quality of the production chain to consumers' health and safety, diffusion of innovations, harmonization of regulations and trade facilitation; see http://www.iso.org/iso/about/ discover-iso_what-standards-do.htm.

37 For instance, with respect to the environmental standards enshrined in the ISO 14000 series, it is estimated that self-certification still outnumbers third-party certification, though these standards were drafted with the purpose of being auditable and certifiable: see DA Wirth, 'The International Organization for Standardization: Private Voluntary Standards as Swords and Shields' (2009) 36 Boston College Environmental Affairs L Rev 79, 85. See also N Roht-Arriaza, 'Shifting the Point of Regulation: the International Organization for Standardization and Global Lawmaking on Trade and the Environment' (1995) 22 Ecology LQ 479, 499, describing the monitoring process with respect to the ISO 9000 standards (and how it applies also to the 14000 series), and Chan (n 30) 1132 , describing the role of third-party registrars and accreditation bodies in the ISO 9000 compliance assessment procedure.

38 See <www.iso.org/iso/resources/conformity_assessment/mechanisms_for_performing conformity_assessment.htm $>$. ISO, however, adopted some guidelines containing the best practices for certifiers (ISO/IEC 17021) and accreditation bodies (ISO/IEC 17011).
}

\section{CAMBRIDGE JDURNALS}


e) Enforcement

First, customers and retailers have the power to sanction deviation from standards simply by refusing to purchase products or services from the producer/provider, or even by terminating existing business relationships. Domestic courts are likely to give considerable weight to non-compliance with standards in tort cases related to product liability (but also in contract cases, particularly when products come with a warranty). ${ }^{39}$ Refusal of certification by certification companies is another powerful means of sanctioning (and signaling to the market) the violation of standards, especially when their spread diffusion induces expectation of compliance.

\section{THE WTO ENDORSEMENT}

Notoriously, ISO and Codex standards have obtained direct relevance in the WTO regime as a consequence of the reference to 'relevant international standards' in the TBT and SPS Agreements. Many authors considered this link between the WTO and the standards as an element that adds binding force to the latter, despite their original voluntary nature. ${ }^{40}$ This view is arguably less the outcome of a reasoned analysis than of a plausible intuition: the Dispute Settlement System of the WTO stands out among other international dispute resolution fora for its high level of effectiveness, both in terms of compulsory and exclusive jurisdiction and of losers' compliance with the terms of the judgment; accordingly, the so-called 'incorporation'41 of the standards into the set of applicable law enforced by panels and Appellate Body cannot but add to the standards' overall strength.

However, it is posited that this position is the by-product of a significant legal and factual simplification, which is ultimately misleading. This section will first explore the exact design of the TBT and SPS renvois and their actual construction and application by the Dispute Settlement Body (section A), and then reflect on the systemic position of this reference in light of the overall

39 See JC Bruno and BD Pynnonen, 'Legal Implications of ISO 9000 Under the UCC' (1996) 75 Michigan Bar J 1076, 1077 : ' . . . if an ISO 9000 adoption statement is made, ISO 9000 could apply to the sale of the product and may be deemed a part of each supply contract', as an express warranty.

40 To list just a few, see DG Victor, 'The Sanitary and Phytosanitary Agreement of the WTO: An Assessment After Five Years' (2000) 32 New York UJ of Intl L and Politics 865, 892; C Chinkin, 'Normative Development in the International Legal System' in D Shelton (ed), Commitment and Compliance: The Role of Non-Binding Norms in the International Legal System (OUP 2000) 21, 31-34; D Bevilacqua, 'Il principio di trasparenza come strumento di accountability nella Codex Alimentarius Commission’ (2007) 57 Rivista Trimestrale di Diritto Pubblico 651, 657; S Picciotto, 'Rights, Responsibilities and Regulation of International Business' (2003) 42 Columbia J of Trantl L 131, 141.

41 See R Howse, 'The Sardines Panel and AB Ruling - Some Preliminary Reactions' (2002) 29 L Issues of Economic Integration 247, 251, noting that since no formal incorporation occurred, panels and the $\mathrm{AB}$ do not enjoy an autonomous interpretive power on Codex standards as if they were WTO norms.

\section{CAMBridge JUURNALS}


scope of the WTO regime (section B). Finally, the hardening narrative and its validity will be reviewed more closely (section $\mathrm{C}$ ).

\section{A. The Normative Framework}

\section{1. $T B T$}

The purpose of the TBT Agreement is to ensure that technical regulations and standards do not result in 'unnecessary obstacles to international trade'. ${ }^{42}$ Article 2(4) of the Agreement requires members to use 'relevant international standards' 'as a basis' for their technical regulations. ${ }^{43}$ This provision must be read in conjunction with article 2(5), ${ }^{44}$ and it means that if national technical regulations $\mathrm{s}^{45}$ that entail a restriction on the imports are challenged before a panel or the Appellate Body ('AB'), they will enjoy a rebuttable presumption of WTO compliance if the defendant State shows that it adopted them 'in accordance with' international standards. Furthermore, if a State considers that the relevant international standards are ineffective or inappropriate to pursue some legitimate objective, ${ }^{46}$ it can deviate from them when adopting TBT measures (and choose the appropriate levels of protection ${ }^{47}$ ). However, challenge to such deviation will be successful if a claimant State is able to show that the standards disregarded by the defendant were in fact effective

42 See Preamble and art 2(2) of the TBT. For a commentary on art 2 TBT see L Tamiotti, in R Wolfrum, PT Stoll and A Seibert-Fohr (eds), Technical Barriers and SPS MeasuresCommentary (Martinus Nijhoff 2007) 210-234. The Preamble also mentions other interests (product quality, health, environment). For some remarks on the 'double telos' of the TBT, a concept that fits our purpose-shift discourse, see MM Du, 'Domestic Regulatory Autonomy under the TBT Agreement: From Non-discrimination to Harmonization' (2007) 6 Chinese J of Intl L 269, 272.

43 The full text reads: 'Where technical regulations are required and relevant international standards exist or their completion is imminent, Members shall use them, or the relevant parts of them, as a basis for their technical regulations except when such international standards or relevant parts would be an ineffective or inappropriate means for the fulfillment of the legitimate objectives pursued, for instance because of fundamental climatic or geographical factors or fundamental technological problems.'

${ }^{44}$ Reading, in the relevant part: 'Whenever a technical regulation is prepared, adopted or applied for one of the legitimate objectives explicitly mentioned in paragraph 2 [national security requirements; the prevention of deceptive practices; protection of human health or safety, animal or plant life or health, or the environment] and is in accordance with relevant international standards, it shall be rebuttably presumed not to create an unnecessary obstacle to international trade.'

45 Annex 1 to the TBT defines a technical regulation as a 'document which lays down product characteristics or their related processes and production methods, including the applicable administrative provisions, with which compliance is mandatory. It may also include or deal exclusively with terminology, symbols, packaging, marketing or labeling requirements as they apply to a product, production or processing method.'

The illustrative list of art 2(4) TBT does not seem to leave much room for such justifications of deviation, as it refers to cases where the standards are not efficient 'because of fundamental climatic or geographical factors or fundamental technological problems'.

47 See the Preamble to the Agreement: 'no country should be prevented from taking measures necessary to ensure the quality of its exports, or for the protection of human, animal or plant life or health, of the environment ... at the levels it considers appropriate'.

\section{CAMBRIDGE JDURNALS}


and appropriate. ${ }^{48}$ All TBT regulations must also comply with the basic principles of non-discrimination ${ }^{49}$ and least-restrictiveness. ${ }^{50}$

The wording of article 2(4), in fact, is not entirely clear. Two concepts in particular seem to be defined too vaguely: that of 'relevant international standards' and that of 'use as a basis'. The expression 'use as a basis' could imply either coincidence or just careful inspiration between the standards and the national measure, and the distinction between this expression and the intuitively more stringent requirement of article 2(5) ('in accordance with') is even more difficult to draw. ${ }^{51}$

The Agreement provides a definition of 'standard' hinging upon the quality of the standard-setter (a standard is a 'document approved by a recognized body' 52 ), but falls short of providing guidance on how to identify recognized bodies. ${ }^{53}$ Further guidance as to the choice of the 'relevant' standards under the TBT may be found in a Decision of the TBT Committee, ${ }^{54}$ which provides some procedural conditions that standards must meet, and also lays down other requirements aimed at favouring the relevance of standards promoting free trade and de-regulation. ${ }^{55}$

48 The onus of proof, indeed, rests with the complainant, see European Communities-Trade Description of Sardines ('Sardines'), WT/DS231/AB/R, Appellate Body Report adopted 23 October 2002, DSR 2002:VIII, 3359, paras 274-275.

49 Art 2(1) TBT. This requirement is covered by the (rebuttable) presumption of art 2(5) TBT.

50 Art 2(2) TBT. This requirement being outside the scope of art 2(5) TBT, it is in principle possible to challenge on grounds of discrimination a measure adopted in accordance with a relevant international standards.

51 The issue is extensively discussed in Howse (n 41, n 4), J Pauwelyn, 'Human Rights in WTO Dispute Settlement' in T Cottier, J Pauwelyn and E Burgi (eds), Human Rights and International Trade (OUP 2005) 205; Pauwelyn (n 17) and Wolfrum, Stoll and Seibert-Fohr (n 42). The relevant $\mathrm{AB}$ reports are EC Measures Concerning Meat and Meat Products ('Hormones'), WT/DS26/ AB/R, WT/DS48/AB/R, Appellate Body Report adopted 13 February 1998, DSR 1998:III, 1033, see para 163 (stating that it is sufficient that a SPS measure is 'founded' or 'built upon' or 'supported by' the international standard) and Sardines (n 48), see para 245 (requiring that the international standard is the 'principal constituent', 'determining principle' or 'fundamental principle' of the TBT measure). At first glance, the 'very close and very strong relationship' deemed by Sardines ( $\mathrm{n} 48$ ) to meet the 'based on' criterion leaves little space for a more stringent requirement of 'in accordance with' under art 2(5) TBT, somehow conflating the two requirements. This result was correctly avoided in Hormones, where art 3(1) and art 3(2) SPS were interpreted by giving careful consideration to the difference between measures 'based on' and 'conforming to' relevant standards (see AB report, para 163).

52 The full definition contained in annex 1 to the TBT reads: 'document approved by a recognized body that provides, for common and repeated use, rules, guidelines or characteristics for products or related processes and production methods, with which compliance is not mandatory. It may also include or deal exclusively with terminology, symbols, packaging, marketing or labeling requirements as they apply to a product, process or production method'.

53 The TBT agreement relies on ISO/IEC Guide 2:2004 for guidance, defining a standardizing body as a 'body that has recognized activities in standardization'. However, this definition is too indeterminate to be of actual help.

54 Decisions and Recommendations Adopted by the Committee since 1 January 1995, WTO Committee on Technical Barriers to Trade, G/ TBT/1/Rev 8, 23 May 2002.

55 This is somewhat at odds with the very role of standards in the TBT framework, which is exactly to provide a sound justification for unilateral market distortion practices (a presumption of legality for domestic policies inconsistent with WTO policies). See R Howse, A New Device for

\section{CAMBRIDGE JOURNALS}


An Annex to the Agreement ${ }^{56}$ provides a set of Good Practices for standardsetting bodies, in which it repeats the principles already spelled out in the TBT. This is to ensure that all standardizing bodies — even those that do not qualify for the requirements of article 2(4) TBT-share the same principles followed by WTO Members adopting technical regulations: non-discrimination, national treatment, most favoured nation, and reliance on available international standards. ${ }^{57}$ This Annex entrusts the ISO/IEC Information Centre with the task of collecting all the notifications from standardization bodies that have accepted the Guidelines. WTO Members have an obligation, codified in article 4(1) TBT, to adopt 'reasonable measures' to ensure that non-governmental standard-setting bodies on their territory abide by the Good Practices of Annex 3 (which otherwise have no direct effect on them).

In the whole TBT Agreement, there are no explicit references to how bodies must be regarded as 'relevant' organizations. However, ISO (along with IEC and ITU) and Codex are - in the respective fields - the most likely candidates to meet the conditions set in article 2(4) TBT, for different reasons. ${ }^{58}$ With respect firstly to ISO, it is not an intergovernmental body and, unlike those of the Codex, its standards are not primarily designed to be incorporated in domestic regulations. In this light, and in the absence of further indications in the TBT, the prominent position of ISO standards as the most obvious 'relevant international standards' is little more than mere historical fact. ISO has risen in authority and credibility over the decades, and by the time of the adoption of the TBT its first-mover advantage had already resulted in three significant privileges: a position of virtual monopoly in several areas of technical standardization, ${ }^{59}$ widespread membership and a quasi-universal competence over almost all conceivable technical issues. ${ }^{60}$

Creating International Legal Normativity: the WTO Technical Barriers to Trade Agreement and "International Standards (draft Paper IILJ Global Administrative Law Series 2004 available at $<$ http://www.iilj.org/GAL/documents/HowsePaper.pdf>) 13.

56 Annex 3 to the TBT: Code of Good Practice for the Preparation, Adoption and Application of Standards. A similar document is the non-binding Annex 4 of the TBT Committee's Second Triennial Review (2000), which also argues for a more inclusive process of decision-making, in which the largest range of interests should have representation.

57 Other recommendations that similarly aim at building consistence within the standard multilayered regimes are the duties to cooperate with international standardizing organizations, to avoid standard duplication, and to adopt performance-oriented standards: see the Code of Good Practice, General Provisions G, H and I.

58 Zúñiga Schroder (n 33) 1226-1227, examines other GATT and WTO documents of an informal nature, including an Annex to the Second TBT Triennial Review, in which other organizations are listed, such as the World Health Organization, the International Organization of Legal Metrology and the Organization for Economic Co-operation and Development. This suggests that, at least in the TBT framework, the list of relevant bodies is open to expansion.

ISO's position in certain areas can be effectively described by referring to the archetypical model of the 'monopolist private regulator', see Cafaggi (n 17) 41.

${ }^{60}$ Considerations of regulatory dominance and credibility were also decisive in the choice of Codex, OIE and IPPC under the SPS, see Zúñiga Schroder (n 33) 1225, fn 7, referring to the preparatory works of the SPS text.

\section{CAMBRIDGE JOURNALS}


Moreover, there is an evident synergy between the TBT and ISO's activity. ${ }^{61}$ First of all, as mentioned above, ISO standards are adopted, inter alia, with the purpose of facilitating international trade, rather than exclusively to improve quality through the implementation of uniform standards. This overlap in the purpose of the two organizations plays a significant role, and proves revealing in assessing the real role of ISO standards (see next section). Furthermore, ISO enjoys observer status before the TBT Committee ${ }^{62}$ and serves as the central accreditation body for the compliance of nongovernmental standard-setters with the Code of Good Practices. ${ }^{63}$

With respect to Codex, the $\mathrm{CC}^{64}$ was identified as the 'recognized organization' in the Sardines case, where the AB confirmed that the European Community ('EC') regulation ${ }^{65}$ restricting the imports of certain sardines was in violation of the TBT, since it was not based on the relevant international standard of the Codex. ${ }^{66}$ The $\mathrm{AB}$ also lays down some benchmarks regarding the features of 'relevant standards' that could be helpful, namely, that such standards need not be adopted by consensus, ${ }^{67}$ and must bear some connection with national regulations.

To date, there are no further judgments that could help to elaborate on the concept of relevant standards and international recognized bodies. ${ }^{68}$ It is unclear, therefore, whether bodies other than the ISO, the Codex and the IEC

61 For a full account of the 'strategic partnership' established between the WTO and ISO, see the ISO/IEC information sheet: 'WTO, ISO, IEC and World Trade', available at < http://www. standardsinfo.net/info/livelink/fetch/2000/148478/6301438/inttrade.html>.

62 As well as with the SPS Committee and the Committee on Trade and Environment (CTE).

63 See provisions C, J and K of annex 3 to the TBT.

64 In the case of the Codex, its definition as 'recognized body' under the TBT is not controversial, since it is expressly recognized in the SPS Agreement: see below. However, the AB makes clear that not all Codex standards are automatically relevant under art 2(4) TBT, and that a case by case assessment is necessary.

65 Council Regulation No 2136/89 of 21 June 1989 laying down common marketing standards for preserved sardines, OJ 1989 L 212.

66 Codex Alimentarius Commission, Codex Standard for Canned Sardines and Sardine-Type Products (Codex Stan 94-1981), art 2(1). EC regulation allowed the use of the word 'sardines' only for the species Sardina pichardus, whereas the Codex standard permitted other species such as the Sardina sagax to be called 'sardines' as well (subject to the attachment of an origin prefix, such as 'Pacific sardines').

67 See Sardines, AB Report (n 48), para 225. See also EC Measures Concerning Meat and Meat Products ('Hormones panel'), Panel Report adopted 18 August 1997, WT/DS26/R /USA 1998:III, 699, para 8.69.

68 In only a few disputes TBT matters were litigated, and sometimes the TBT part of the claim was disregarded by the panel. As of October 2011, only a handful of cases are to be mentioned. A case similar to Sardines was EC-Scallops. However, the parties settled the dispute, thus the panel report remained unadopted see European Communities - Trade Description of Scallops-Request by Canada, WT/DS7/R, 5 August 1996, unadopted, DSR 1996:I, 89; WTO Panel Report, European Communities - Trade Description of Scallops-Requests by Peru and Chile, WT/DS12/ R, WT/DS14/R, 5 August 1996, unadopted, DSR 1996:I, 93. In EC-Asbestos the panel considered complaints under GATT and overlooked the TBT claims. See WTO Panel Report, European Communities-Measures Affecting Asbestos and Asbestos-Containing Products, WT/ DS135/R and Add.1, adopted 5 April 2001, modified by Appellate Body Report, WT/DS135/AB/ R, DSR 2001:VIII, 3305. On 2 September 2011 a panel report was circulated, regarding the dispute

\section{CAMBRIDGE JDURNALS}


will meet the requirements of article 2(4) TBT. Likewise, given the universal reach of ISO standards, it is not clear whether alternative non-governmental standards - if used as a basis for national regulations - will be able challenge the position of the ISO standards, and obtain DSB clearance (on the different issue of private standards, see below).

\section{SPS}

The SPS Agreement, in turn, aims to reconcile the tension arising between free trade and the proliferating regimes of food safety. In the Preamble to the Agreement, the members make clear that the purpose of the SPS is both 'to improve the human health, animal health and phytosanitary situation in all Members' and to establish 'a multilateral framework of rules and disciplines to guide the development, adoption and enforcement of sanitary and phytosanitary measures in order to minimize their negative effects on trade'. This double purpose might cause difficulties in the interpretation of the SPS provisions, insomuch as any attempt to relay on a purposive interpretation would have to take into account these two aspirations, which are often in a relationship of tension.

SPS provisions are intended, on the one hand, to facilitate mutual recognition of good faith standards designed to ensure health protection and, on the other hand, to expose all those standards that are, in fact, market restrictions disguised as safety regulations dictated by national policies. Since the distinction between good-faith and bad-faith regulations is in the mind of the national regulator and is typically hard to appreciate, the SPS Agreement introduces what is contended to be the most objective benchmark reasonably available to assess the appropriateness of domestic food safety regulationsthe 'scientific foundation' ${ }^{69}$ Any SPS measure must satisfy other requirements besides the scientific justification (accompanied by the relative risk-assessment criterion) and the non-discrimination mantra; ${ }^{70}$ it must be the least traderestrictive available among those that ensure the same level of protection ${ }^{71}$ (the one every State is entitled to choose freely) ${ }^{72}$, and if it reflects a level of

United States-Measures Affecting the Production and Sale of Clove Cigarettes WT/DS406/R. Although TBT-related claims are central and in particular art 2(5) TBT is discussed at length, the case did not hinge upon the role of international standards. See para 7.458, and footnote 813: 'In response to a question from the Panel, both parties agreed that there is no relevant "international standard" within the meaning of the second sentence of Article 2.5 of the TBT Agreement.' It is possible to monitor the status of TBT-related disputes at $<$ http://www.wto.org/english/tratop_e/ dispu_e/dispu_agreements_index_e.htm?id=A22\#selected_agreement $>$.

69 See art 2(2) SPS: 'Members shall ensure that any sanitary or phytosanitary measure is applied only to the extent necessary to protect human, animal or plant life or health, is based on scientific principles and is not maintained without sufficient scientific evidence.' The risk assessment requirement (art 5(1) SPS) is the main pillar of the scientific basis for a SPS measure.
70 Art 2(3) SPS
71 Art 5(4) and 5(6) SPS.
72 Art 3(3) SPS.

\section{CAMBRIDGE JDURNALS}


protection that is not comparable to that adopted by the State with respect to similar risks or threats, the measure will be subject to additional scrutiny. ${ }^{73}$

Like the TBT, the SPS (article 3(1)) requires Member States to base national regulations on available international standards. ${ }^{74}$ Unlike in the TBT, however, the SPS itself clarifies what those standards are, and appoints the Codex Commission (along with the International Office of Epizootics and the International Plant Protection Convention) as the body empowered to adopt 'relevant standards' on food safety under the SPS. ${ }^{75}$

The role of article 3(2) SPS is similar to that of article 2(5) TBT, as it provides a presumption of WTO-compliance for national regulations conforming to international standards. ${ }^{76}$ Article 3(3) SPS, ${ }^{77}$ in turn, specifies the conditions that a national regulation which is more stringent than required by international standards must meet not to result in a violation of the SPS and the obligations applicable to the GATT. Namely, if the complainant discharges the burden to make a prima facie case of violation, defending States must be able to provide a scientific justification ${ }^{78}$ when they diverge from international standards and pass more stringent (read: more trade-restrictive) regulations. Substantiating this scientific basis, importantly, is not a means to rebut a presumption of the measure's illegality (that is to say, a justification for a prima facie violation of the SPS), but a positive obligation, in discharging which a

73 Art 5(5) SPS. Whereas there is no obligation to ensure internal regulatory consistency (States are free to regulate similar risks differently), States are encouraged to adopt homogeneous measures, and are not allowed to use their right to set a higher level of protection in order to implement unjustified discriminations or disguised restrictions, see Hormones (n 51) para 213. On these consistency requirements, see also the Appellate Body Report, Australia-Measures Affecting Importation of Salmon (Australia-Salmon), WT/DS18/AB/R, adopted 6 November 1998, DSR 1998:VIII, 3327, para 178 .

74 See art 3(1), reading in the relevant part: 'Members shall base their sanitary or phytosanitary measures on international standards, guidelines or recommendations, where they exist'.

75 See annex A to the SPS Agreement, art 3. The IOE and the IPPC are, respectively, the reference bodies for animal health and plant protection. Art 3(d) is an open clause, stating that for matters not covered by the Codex, the IOE and the IPPC, a TBT-like method applies, and States can rely on standards developed by international organizations whose membership is open to all WTO members. This explicit reference can be read as an 'ex post recognition of [the] 'public functions' [of these bodies] which extends the scope of legal effect to third parties,' see Cafaggi (n 17) 29. For recent qualification of the Codex Commission as a 'relevant international organization' see United States-Continued Suspension of Obligations in the EC-Hormones Dispute, WT/DS320/R, Panel Report adopted 31 March 2008, para 7.446.

${ }^{6}$ In fact, this presumption is wider, since art 2(5) TBT, as seen above, provides for an expressly rebuttable presumption, and only with respect to the requirement of no unnecessary trade restrictiveness.

${ }^{77}$ Under which regulations stricter than those based on standards are permitted if there is a scientific justification, or as a consequence of the level of sanitary or phytosanitary protection a Member determines to be appropriate'.

78 The Parties added a footnote to art 3(3) SPS to clarify the meaning of scientific justification, which reads: "there is a scientific justification if, on the basis of an examination and evaluation of available scientific information in conformity with the relevant provisions of this Agreement, a Member determines that the relevant international standards, guidelines or recommendations are not sufficient to achieve its appropriate level of sanitary or phytosanitary protection'.

\section{CAMBridge JUURALS}


defendant can demonstrate it has satisfied the conditions necessary to enjoy its primary right not to base its measures on international standards. ${ }^{79}$

Importantly, the rules of article 3(3) SPS and 2(4) TBT set the conditions for States to depart from standards without violating their WTO obligations. However, the analysis of these provisions is intentionally limited because, as will come clear below, they are arguably (and sometimes literally, as in article 3(3) SPS, first part) designed specifically to regulate national measures that tighten up the protection granted by international standards, not those that detract from such level of protection.

\section{B. Liberalization Versus Positive Harmonization}

It is well established that the 1947 GATT system was very much focused on trade liberalization, through the control of trade barriers at borders (tariffs, quotas and the like) and internally (regulations). After 1995, with the entry into force of the whole Doha treaty package, the focus of the new WTO has shifted more to the control of 'behind-the-border' measures, that is, regulatory measures. ${ }^{80}$ In particular, in the fields of food safety, health matters and environmental protection the shift has been apparent, and the paradigm of 'embedded liberalism' 81 has mutated into a system where the need to ensure non-discrimination and to eradicate trade obstacles has started to interfere with national policies in a direct way. ${ }^{82}$

International standards are not formally incorporated in the WTO legal regime, which continues to profess its liberalization agenda based on de-regulation. ${ }^{83}$ However, compliance with the standards entitles States to some presumption of WTO-compliance, and this - at least indirectly — cannot but bring about a certain degree of harmonization of national technical

\footnotetext{
79 This specification has a central role in the allocation of the onus probandi regarding the violation of trade rules. Whereas the Panel had found that art 3(3) SPS works as an exception (see Hormones panel (n 67), paras 8.51 to 8.54), in fact, the AB ruled instead that it rests with the complainant, alleging a violation of art 3(3) SPS, to show at least a prima facie lack of scientific basis for the challenged measure. In other words, deviation from the standards 'is not penalized' with a shift of the burden of proof on the defendant. See the AB report in Hormones (n 51) para 171 and Sardines ( $\mathrm{n} 48$ ). This is consistent with the above remark that deviation from the standards does not trigger a presumption of illegality, in which case the defendant should have the burden of rebutting the presumption. On the difference between this doctrine and the one adopted with respect to the exceptional rules of art XX GATT and the Enabling Clause, see M Matsushita, 'Human Health Issues in Major WTO Dispute Cases' (2009) 4 Asian Journal of WTO and International Health Law and Policy, 1. See Howse (n 4) 388, as regards the similar provision of art 2(4) TBT.

80 A Guzman, 'Global Governance and the WTO' (2004) 45 Harvard Intl LJ 303.

81 JG Ruggie, 'International Regimes, Transactions, and Change: Embedded Liberalism in the Postwar Economic Order' (1982) 36 Intl Organization 379, 398.

${ }^{82}$ M Ming Du, 'Domestic Regulatory Autonomy under the TBT Agreement: From Nondiscrimination to Harmonization' (2007) 6 Chinese J of Intl L 269, 272.

${ }^{83}$ S Cassese, Shrimps, Turtles and Procedure: Global Standards for National Administrations (Working Paper 2004/4 IILJ Global Administrative Law Series 2004) : '[standards] do not create direct, legally binding obligations upon the States.' See also Hormones AB Report (n 51) para 165.
}

\section{CAMBRIDGE JDURNALS}


regulations, which converge towards the safe haven granted by the 'use' of standards.

It is necessary to clarify the nature of this harmonization process. The WTO has been hailed as the archetypical regime of negative harmonization, or (better) negative integration. ${ }^{84}$ Standards, in turn, are among the typical tools to promote regulatory harmonization. It is clear, just by referring to these simplistic definitions, that both the WTO and international standards regimes favour harmonization but, in fact, they promote different kinds of harmonization (respectively, negative integration and regulatory harmonization). ${ }^{85}$ We anticipate a concept that will be explored in more detail in part $\mathrm{C}$ below; whereas standardization purports to encourage harmonization by setting minimum protection benchmarks which ought not be lessened by national regulators (eg a certain vegetable cannot contain more than $\mathrm{X}$ milligrams of pesticide residues $\rightarrow$ national regulators can adopt different residue standards, but should not increase the X value), the WTO regime aims at discouraging measures that, by imposing additional burdens on producers and exporters, restrict market access (in the same example, WTO provisions discourage national regulators from decreasing the $\mathrm{X}$ value). ${ }^{86}$

The harmonization effect of TBT and SPS is not embodied in the deference to standards that they proclaim, but in the whole set of procedural requirements (in terms of non-discrimination, least distortion, scientific or reasonable motivations) that encourage a progressive rapprochement of the modalities by which regulations are adopted, rather than of their content. The main innovation with respect to the GATT model, indeed, is that under the SPS and TBT national measures can be challenged and struck down even if they are not discriminatory; it is no longer true that States can regulate freely insofar as they do not discriminate. In fact, under the SPS and TBT unnecessary,

84 A Reich, 'The WTO as a Law-Harmonizing Institution' (2004) 25 U of Pennsylvania J of Intl Economic L 362. For an accurate account of the concept of negative integration and its application in economic communities, see F Ortino, Basic Legal Instruments for the Liberalisation of Trade: a Comparative Analysis of EC and WTO Law (Hart Publishing 2004) 18 and bibliography referred to therein, in particular FW Scharpf, 'Negative and Positive Integration in the Political Economy of European Welfare States' in G Marks, FW Scharpf, PC Schmitter and W Streeck (eds), Governance in the European Union (SAGE 1996) 15.

${ }^{85}$ In other words, the WTO does not try to bring about regulatory convergence. It is disinterested in national policies, as long as they do not affect international trade, and whenever they do, it just makes sure that the least restriction to trade is provoked. PC Mavroidis Market Access in the GATT (Research Paper 7/2008 STALS 2008 available at < http://www.stals.sssup.it/ site/files/stals_Mavroidis.pdf >) 7: 'national policies are being unilaterally defined and, to the extent that there is an international spillover, it will be internalized through nondiscrimination. ... Trade will not harmonize societal preferences. Trade is not the overarching value in the WTO contract. Trade comes after respect of regulatory diversity.' On mutual recognition, harmonization and regulatory authority, see JP Trachtman, 'Regulatory Jurisdiction and the WTO' in WJ Davey and JH Jackson (eds), The Future of International Economic Law (OUP 2008) 193.

86 This species of harmonization is purported to be the one that negotiators of the SPS had in mind: see Buthe (n 3) 242: 'International harmonization would force countries with stringent standards to justify those standards, providing opportunities for agricultural exporters to expose and potentially block protectionist measures.'

\section{CAMBridge JUUNALS}


ineffective, non-substantiated regulatory schemes are subject to review, inasmuch as they result in an unjustified burden for trade, regardless of their discriminatory nature.

Bearing these points in mind, it is useful to pause to consider the role of domestic technical regulations within the international trade regime. States often enact trade policies designed to pursue economically questionable results such as protection of domestic producers from the competition of foreign products, and/or the improvement of their 'terms-of-trade,' ${ }^{87}$ when their market power as importers is such that their buying policies affect significantly the world price. ${ }^{88}$ Both protectionism and terms of trade manipulation are typically achieved by imposing tariffs on imports (it strengthens the competitive position of domestic producers, and forces foreign ones to lower the price of their products). Since tariff increases are outlawed in the WTO system (and so are tariff-comparable measures, like quotas and consumption taxes), another option available is the adoption of technical regulations targeting foreign products; by imposing additional standards on foreign producers a State can shift abroad the increase in cost of a certain product (caused by the partial closure of the internal market) and at the same time improve its terms-of-trade. ${ }^{89}$ To avoid States using these manipulative strategies that result in trade externalities and overall inefficiency, the GATT and the WTO endorsed the non-discrimination principles of MFN and NT, under which regulatory measures shall be applied uniformly to foreign and domestic producers.

Despite the imposition of such non-discrimination requirements on national regulations, States nevertheless have the incentive to raise regulatory standards, in order to make foreign suppliers bear at least part of the cost of ensuring a better terms-of-trade ratio, ${ }^{90}$ in the form of regulatory compliance cost, ${ }^{91}$ or more simply to raise a protection for the domestic industry. This called for the enactment of a new generation of post-discriminatory rules, ${ }^{92}$ the TBT and SPS Agreements were adopted precisely to counter the rise of regulatory measures that, although being non-discriminatory on their face, entailed de

\footnotetext{
87 For a definition of the 'terms of trade' expression see the Deardoff's Glossary of International Economics, available at <http://www-personal.umich.edu/ alandear/glossary $>$ : ' 1 . The relative price, on world markets, of a country's exports compared to its imports.'

88 An accurate description and distinction of these two trade-policy goals is contained in DH Regan, 'What Are Trade Agreements for?-Two Conflicting Stories Told by Economists, with a Lesson for Lawyers' (2006) 9 J of Intl Economic L 951.

89 RW Staiger and AO Sykes, International Trade and Domestic Regulation (Working Paper 15541 NBER 2009) 19-22.

${ }^{90}$ For instance, governments pursue terms-of-trade purposes when they try to safeguard exporters' revenues at the expense of global efficiency.

91 Staiger and Sykes (n 89) 29; Trachtman (n 85) 195; G Marceau and JP Trachtman, 'Responding to national concerns' in D Bethlehem and others (eds), Oxford Handbook of International Trade Law (OUP 2009) 209, 235.

92 RE Hudec, 'Science and Post-Discriminatory WTO Law' (2003) 26 Boston College Intl and Comparative L Rev 185, 187.
}

\section{CAMBRIDGE JDURNALS}


facto discriminatory effects, or simply constituted an unnecessary trade restriction. ${ }^{93}$

In fact, WTO endorsement of international standards is little more than an authoritative instruction moulding Member States' litigation strategies and a yardstick designed to simplify judicial review by panels and AB. ${ }^{94}$ The rationale behind the presumptions described above is one of economic efficiency; regulations based upon widely agreed standards are less likely to cover a State policy aimed at externalizing the cost of compliance by shifting it onto foreign players; therefore, they are presumed not to distort free trade. To put it differently, international standards are presumed to comply with all or some of the requirements that, in their absence, national regulatory measures are in turn required to meet to pass the SPS and TBT test. ${ }^{95}$

With these factors in mind, the rhetoric of 'delegation of regulatory powers ${ }^{\prime}{ }^{6}$ appears perhaps too far-reaching; the following section considers the 'hardening' theory, based on the suggestion that standards in the WTO mutate and assume a trade-driven function.

\section{No Hardening}

\section{Reverse Hardening (Standards are used as a Protection Ceiling)}

As observed above, several scholars link the quasi-judicial functions of DSB bodies with the effectiveness of ISO and Codex standards, and consider that the latter have undergone a process of hardening, as they are enforced in the WTO system within a framework of compulsory jurisdiction. For example, Pereira states that: 'If one considers that the Appellate Body has been interpreting the

\footnotetext{
93 Note that according to DH Regan (n 88) 980-981, SPS and TBT's requirements for efficient standards (and trade agreements in general) are aimed only at preventing protectionism, and are not designed to exorcise terms-of-trade manipulation, a goal that is rarely used as an actual regulatory purpose by State authorities. However, this conclusion is in consequence of Regan's persuasion (at 986-988) that the SPS and TBT are solely concerned with hidden protectionist measures and should not be used to strike down merely inefficient or unnecessarily restrictive measures, to the point of doubting "whether the substantive provisions of the SPS and TBT Agreements - about the use of international standards, and risk assessment, and the avoidance of unnecessarily traderestrictive measures - are a good thing.'

94 See PC Mavroidis, 'Come together?: Producer Welfare, Consumer Welfare and WTO Rules' in EU Petersmann (ed), Reforming the world trading system: legitimacy, efficiency and democratic governance (OUP 2005) 277, 285; Buthe (n 3) 246, stressing that resort to standards was a device through which SPS negotiators intended to simplify the scientific review of national measures, avoiding costly case by case risk assessment procedures.

${ }_{95}$ See US-Hormones suspension, panel report (n 75), para 7.644: 'standards, guidelines or recommendations .... are based on risk assessments that meet the requirements of the SPS Agreement. This means, therefore, that there was sufficient evidence for [the standard-setting body] to undertake the appropriate risk assessments'.

96 G Marceau and JP Trachtman, 'The Technical Barriers to Trade Agreement, the Sanitary and Phytosanitary Measures Agreement and the General Agreement on Tariffs and Trade' (2002) 36 J of World Trade 811, 838; Buthe (n 3).
}

\section{CAMBRIDGE JOURNALS}


relevant provisions of the SPS Agreement in a way that strips national regulators' discretion to deviate from international standards and that members may eventually face sanctions if noncompliance persists, Codex standards might be undergoing a hardening process. 97 This may be misleading, in that it reinforces the impression that deviation from Codex standards triggers violation of WTO obligations, as if compliance with (or violation of) standards and compliance with (or violation of) WTO rules go hand in hand. The hardening reference, indeed, suggests that forced compliance with WTO rules results, indirectly, in higher compliance with standards.This is incorrect, because by definition compliance with standards and compliance with trade obligations mutually exclude one another, ${ }^{98}$ save for the 'fortunate' situations governed by articles 2(5) TBT and 3(2) SPS. ${ }^{99}$

Note that the quotation above is from Pereira's comment on $E C$-Hormones, a case in which the EC was found to violate relevant trade obligations ${ }^{100}$ for adopting domestic food safety regulations that were more stringent than those required by relevant international standards, and for being unable to justify them based on scientific evidence (risk assessment). ${ }^{101}$ That means that the violation of WTO rules was not caused by a violation of the standards, but by the imposition of higher (but ultimately unjustified) standards. ${ }^{102}$ If the EC had violated the Codex standards by adopting weaker requirements than those incorporated therein (eg, by permitting the distribution of meat containing a food additive beyond the maximum use level established in the Codex), no claim would be triggered under the WTO.

In other words, the above equivalence should be re-phrased: deviation from standards entails noncompliance with WTO obligations only in the sense that over-compliance with standards entails noncompliance with WTO obligations. Violation of standards (that is, regulatory measures less restrictive than required

\footnotetext{
97 Pereira (n 7) 1704.

98 Allegedly, Japan lowered its domestic pesticide standards which provided greater public health protection than was required by Codex standards, in order to prevent WTO litigation with New Zealand or the US, see LM Wallach, 'Accountable Governance in the Era of Globalization: The WTO, Nafta, and International Harmonization of Standards' (2002) 50 U of Kansas L Rev 823, 838; Y Naiki, 'Accountability and Legitimacy in Global Health and Safety Governance: The World Trade Organization, the SPS Committee and International Standard setting Organizations' (2009) 43 J of World Trade 1255, 1276; Victor (n 40) 879. See Hormones AB Report (n 51) para 177.

99 Pauwelyn (n 17) 213 succinctly phrases this interpretation as: 'the incentive to harmonize is limited to the safe-haven offered by conforming to the standard.' Note that the Panel, when analyzing the structure of art 2 TBT and 3 SPS, excluded the possibility that departure from a standard could be construed as an exception: 'the Appellate Body found no general rule-exception relationship even though the word 'except' was used in both Article 3.1 of the SPS Agreement and Article 2.4 of the TBT Agreement.' See EC-Tariff Preferences, report of 1 December 2003, WT/ DS246/R, fn 452.

101 See Hormones (n 51) paras 208-209.

102 See Buthe (n 3) 228: 'the freedom to adopt more stringent standards is subject to more, not fewer constraints.'
}

\section{CAMBRIDGE JOURNALS}


by international standards), in effect, would raise no issue of compliance with WTO rules, at least before the DSB. ${ }^{103}$ We briefly explore below the abstract possibility of WTO violation through below-standard measures (see Part (B) infra).

This becomes even clearer if we think that the presumption of WTOcompliance is accorded as far as the international standard is not exceeded; standards mark the maximum level of protection that domestic policies can pursue without needing further justification; they play a 'ceiling' function in the trade regime. ${ }^{104}$ To the contrary, harmonized standards are traditionally conceived as minimum standards by which all countries must abide, yet being able, severally, to choose more stringent protection policies and objectives. ${ }^{105}$ Standards drafted and adopted with the purpose of implementing and developing food safety or product quality end up being used in the WTO regime as a protection cap, whose role is to discourage States that want to adopt stricter policies. This calls into question the original purpose of the ISO and Codex standardization activities, besides undermining the 'hardening rhetoric'. 106

103 See J Wouters, A Marx and N Hachez, Private Standards, Global Governance and Transatlantic Cooperation, the Case of Global Food Safety Governance (Working Paper Leuven Centre for Global Governance Studies 2009) 14-15: 'Any food safety regulation which is more lenient than a Codex Alimentarius Standard does not violate the SPS Agreement.' See also D Kalderimis, 'Problems of WTO Harmonization and the Virtues of Shields Over Swords' (2004) 13 Minnesota J of Global Trade 305, 337-341 : 'SPS and TBT Agreements ... do not prescribe any essential requirements because they do not promote any non-trade values. The WTO does not provide minimum standards of health protection, or specify minimum levels of technical regulations'. See also Wirth (n 37) 95. Contra, arguing that the obligation not to deviate from standards is enforceable also in case of looser regulations, see Howse (n 4) 395. See also Hormones (n 51) para 165, noting that it would be excessive to assume that SPS signatories intended to vest more stringent voluntary international standards with obligatory force and that, under the in dubio pro mitius general principle of international law, States should be allowed to maintain their 'less burdensome' obligations. The AB refers to 'sovereign states' as a whole, failing to grasp the core of the issue: technical requirements that are burdensome for some States (exporters) might be beneficial for others (importers). The AB's remark, thus, should be read in the sense that exporters could not deliberately give up the voluntary nature of international standards, to their own detriment.

104 Wouters, Marx and Hachez (n 103) 15 notes that SPS uses the standards as 'upper limits'. Likewise, Landwehr in Wolfrum, Soll and Seibert-Fohr (n 42) 414: 'the [SPS] Agreement has effectively changed the nature of these standards: while the standards were originally developed as minimum standards, they are now used in dispute settlement proceedings as ceilings which-in principle - have to be observed.' Similarly, Wirth (n 37) 96.

105 Curiously, the ISO itself, on its website, refers to the 'floor' concept of common standards, even precisely in connection with their trade function: 'International Standards create 'a level playing field' for all competitors on those markets. The existence of divergent national or regional standards can create technical barriers to trade.' On Codex standards as minimum quality standards, see Livermore (n 4) 768, 771.

106 Pauwelyn (n 17) $213 \mathrm{ff}$ raises the question whether TBT and SPS could be used to ratchet-up national policies or solely to use international standards as a ceiling. His accurate reading of the TBT and SPS provisions seems to leave space for the 'upward harmonizing' view: since members 'shall' use standards as a basis for regulations (art 2(4) TBT and 3(1) SPS), it would seem that there is an actual WTO obligation not to pierce the floor of standard protection by adopting looser regulations. Even though it could be formally true, some normative elements and a factual

\section{CAMBRIDGE JOURNALS}


As simple as this reading is, it appears well-suited to explain the actual dynamics between standards and trade rules. Among the alternative arguments supporting the hardening rhetoric, there is the textual interpretation of the TBT and SPS. Indeed, at least literally, articles 2(4) TBT and 3(1) SPS use the language of obligation (members 'shall' use standards as a basis for their measures), which in itself might be construed as requiring States not to deviate from standards in any circumstance, not even leveling them downwards. This construction is so literal that it appears somewhat stretched, and one cannot disregard what the whole agreement makes clear, even if it is not spelled out in single provisions. That is, a fair interpretation of the terms of the treaty 'in their context and in the light of its object and purpose'107 definitely leads the interpreter to acknowledge the trade-concerned nature of such 'obligation': deviations are regulated and discouraged only insofar as they affect trade. As Howse rightly notes, concerning the TBT regime: 'The presumption in Article 2(5) suggests that Article 2(4) is intended to serve a similar function to Article 2(5), ie, to limit trade-restrictiveness in domestic regulations, not to impose the normativity of international standards as such.' 108

With the SPS Agreement, the teleological aspect is even more immediate; article 1(1) specifies that the whole agreement only applies to national regulations affecting trade, and the $\mathrm{AB}$ ingenuously provides a soft rendition of the 'obligation' of article 3(1) ('[u]nder Art. 3(1) ... a member may choose to establish an SPS measure that is based on the existing relevant international standard.' $)^{109}$

A final aspect of the use of standards in the TBT must be considered, for the sake of completeness. A complaining State could allege that the defendant's

consideration virtually make this reading unlikely, or irrelevant. First, as Pauwelyn concedes, looser domestic regulations would hardly meet the requirements of art 1(1) SPS (the Agreement applies only to measures that are likely to affect international trade), and the TBT repeatedly links the function of standards with the risk of trade distortion (implicitly ignoring their supposed relevance as minimum protection floor), in the preamble and in art 2(1), 2(2), 2(4), 2(5), 2(9). Moreover, more pragmatically, it is highly unlikely that a member would challenges a domestic regulation of another member imposing looser standards, as this measure could not (negatively) affect its interests (as an exporter); as Pauwelyn states: 'The odd result of this is that the WTO would then essentially grant a request to restrict trade more (that is, ask the defendant to impose stricter SPS measures).' Likewise Victor (n 40) 883-884 acknowledges that in the SPS looser national regulations may still be challenged, but not so much in that they deviate from standards, but only under art 5 tests (risk assessment and scientific justification). For instance, low-protection national regulations may prove burdensome just because they were only adopted in one country, making it relatively expensive for companies to adapt their activity just to gain access on that market. In any event, Victor concedes that the hypothesis is unlikely, "because demonstrating the existence of a trade effect from weak SPS measures is difficult and bringing disputes is costly'.

108 See Howse (n 4) 387.

109 See Hormones (n 51) para 171, emphasis added.

\section{CAMBRIDGE JDURNALS}


measure, although adopted on the basis of an international standard, still creates an unnecessary restriction of trade under article 2(2) TBT, ${ }^{110}$ and is therefore illegitimate. In other words, there could be the case where international standards are more trade restrictive than necessary to fulfill the 'legitimate objectives' pursued by the State. This follows from the concededly rebuttable nature of the presumption set forth in article 2(5) TBT. If this is the case, the complainant has the additional burden of showing that complying with standards (as pursuant to article 2(4) TBT) did not lead the defendant to choose the actually least-restrictive viable option (as required by article $2(2)$ TBT). ${ }^{111}$

A similar scenario may occur also in the SPS regime. However, since the requirement of least-restrictiveness of article 5(6) explicitly spares article 3(2) measures, it is difficult to hypothesize how these latter could be demonstrated to violate other relevant SPS provisions. ${ }^{112}$

The fact that the TBT discourages (by means of an aggravated burden of proof) trade-concerned claims aimed at challenging the application of the standards could seem to support the argument that the WTO mechanism favours harmonization and the implementation of international standards even when they are not efficient, to the detriment of free trade. ${ }^{113}$ However, while this argument may be convincing in stressing the force of the presumption granted by standards, it has little to do with our ceiling argument based on the level of protection; by definition, the least-restrictive test is premised on a fixed level of protection. Moreover, if trade-inefficient standards are somehow in need of justification under the TBT, it follows that the general rule is that least restrictive measures are generally legal, be they based on standards or not. If anything, this tells us that not even the safe haven provided by standards is that safe, and certain claims meeting precise proof requirements could carry the day and win against measures based on (inefficient) standards, invalidating the presumption. ${ }^{114}$

The intuition that SPS and TBT use standards only to draft a black-list of more stringent measures to hit, which in principle ensure higher protection, is supported by the nature of the disputes brought so far before the panels

\footnotetext{
110 Reading, in the relevant part: 'Members shall ensure that technical regulations are not prepared, adopted or applied with a view to or with the effect of creating unnecessary obstacles to international trade. For this purpose, technical regulations shall not be more trade-restrictive than necessary to fulfill a legitimate objective, taking account of the risks non-fulfillment would create.'

111 This burden is additional to the one typically reserved to complainants, that is, proving the existence of trade impairment subsequent to the adoption of the challenged measure.

112 This hypothesis must nevertheless be taken into account, at least to maintain a distinction between the two benefits granted by art 3(2) SPS. On one hand, the necessity requirement is irrefutably satisfied ('shall be deemed to be necessary'), on the other hand, every other provision of the SPS and the GATT is simply 'presumed' to be complied with.

113 See Howse (n 4) 388-389.

114 To the contrary, if any importance were attached to the dynamics of the burden of proof in the treatment of standards, it would be clear that the hardest task is assigned to States that want to 'surpass' the standards: they have to prove the standards' inefficiency and inappropriateness.
}

\section{CAMBRIDGE JUURALS}


and the $\mathrm{AB}$ (invariably relating to regulations more stringent than required by relevant standards), ${ }^{115}$ but also by the nature of the disputes that were settled or resolved before getting to the adjudication phase. Observing the breakdown of the 'trade concerns' (a revealing formula indicating complaints raised by members against other members' regulations) raised before the SPS or TBT Committee, it emerges that they systematically target new stringent regulations, often adopted by more developed members. ${ }^{116}$ This means that SPS and TBT do not regard themselves as having jurisdiction over lower-thanstandards technical regulations, or at least that no member is concerned about them. ${ }^{117}$

115 To date, only five disputes hinging upon the application of the SPS have been brought before the panels and the AB: EC-Measures Concerning Meat and Meat Products, Panel Report WT/ DS26/R/USA adopted 18 August 1997; AB Report WT/DS26/AB/R adopted 16 January 1998. Australia - Measures Affecting Importation of Salmon, Panel Report WT/DS18/R adopted 12 June 1998; Appellate Body Report WT/DS18/AB/R adopted 20 October 1998. Japan-Measures Affecting Agricultural Products (Apples), Panel Report WT/DS76/R adopted 27 October 1998; Appellate Body Report WT/DS76/AB/R adopted 22 February 1999. Japan-Measures Affecting the Importation of Apples, Panel Report WT/DS245/R adopted 15 July 2003; Appellate Body Report WT/DS245/AB/R adopted 26 November 2003. For a full description of this case law, see Matsushita ( $\mathrm{n} \mathrm{79)}$ ). Other disputes were filed relating to SPS provisions without triggering the adoption of a panel report, see WT/DS3 Korea-Measures Concerning the Testing and Inspection of Agricultural Products; WT/DS144, United States-Certain Measures Affecting the Import of Cattle, Swine and Grain from Canada and WT/DS100, United States-Measures Affecting Imports of Poultry Products. The GMO disputes against the EC (WT/DS291, 292 \& 293, European Communities-Measures Affecting the Approval and Marketing of Biotech Products) were not appealed before the AB. In 2010, SPS norms were discussed by the panel in US-Certain Measures Affecting Imports of Poultry from China Panel Report WT/DS392/R adopted 29 September 2010, but the dispute did not touch upon relevant international standards. Similarly, in the New Zealand Apples dispute art 3 SPS was not invoked nor applied (see Australia-Measures Affecting the Importation of Apples from New Zealand, Panel Report WT/ DS367/R adopted 9 August 2010; Appellate Body Report WT/DS367/AB/R adopted 29 November 2010). As for TBT-cases, see cases above (n 69).

116 See the data provided in Naiki (n 98) 1265-1266. In fact, in the case of TBT, China is also a frequent target of trade concerns, presumably due to the difficulty of exporters to adapt their business to new China-specific registration or verification requirements, quite apart from their stringency. As for SPS trade concerns, see the data available in T Epps, International Trade and Health Protection (Elgar Northampton 2008) 32-33, and V Zahrnt 'Transparency of complex regulation: how should WTO trade policy reviews deal with sanitary and phytosanitary policies? (2010) World Trade Rev-FirstView 13: 'What [exporters] target is poor risk assessment, overly trade-restrictive measures, and levels of protection that are well above the implementing country's average level as well as above international standards.'

117 A study of the negotiation process leading to the adoption of the SPS (Buthe (n 3) 239-241) seems to confirm that the only rationale for the proposals to take into account international standards was that of 'minimizing the adverse effects that [safety] regulations and barriers can have on trade'. Excerpt from WTO, Ministerial Declaration of 20 September 1986, MIN(86(/W/19, 25 ILM 1623, 1626 (1986). See also the dictum of the panel in US Poultry (n 115) para 5.75: 'it is clear that an SPS measure can only be introduced provided that it is based on international standards, guidelines and recommendations where they exist ... This is to ensure that measures are not taken arbitrarily and are not used as a tool for manipulating international trade.' (emphasis added)

\section{CAMBRIDGE JOURNALS}




\section{Professor Scott's Rebuttal of the upwards Harmonization Hypothesis}

This finding (standards are used as a ceiling, and States are free to adopt less stringent measures), concededly, is not reflected in an explicit text of WTO law, nor has it been clearly endorsed by a panel or the AB. Moreover, scholars appear not to have examined this aspect rigorously. ${ }^{118}$ This relative disinterest of the regulator, the adjudicator and the commentators would have, if any, the effect of strengthening the premise of the present analysis; State measures that are less stringent than required by international standards are WTO-irrelevant, and this is why they understandably raise little interest.

However, this very issue (in the SPS system) was discussed at some length by Professor Joanne Scott, hence it is appropriate to give an account of her views. ${ }^{119}$ Scott's analysis aimed at discussing the possibility that international standards be used to ratchet-up States' level of protection, a hypothesis premised on the literal reading of article 3(3), first part of the SPS (which only regulates how to deal with stricter-than-standards measures), whereby 'upwards derogation would be permitted ... but downwards derogation would be entirely precluded'. ${ }^{120}$ This is the antithesis of the claim advanced in this article, and if correct, it would imply that standards are used to build a minimum protection floor, rather than a ceiling.

Scott notes that the purpose of the WTO regime (promoting trade) is not sufficient to discard the floor-hypothesis altogether, as the purpose of the SPS is spurious (see above) and a sporadic health-friendly use of the agreement is not unthinkable. ${ }^{121}$ Nevertheless, the floor-hypothesis can be rebutted with other objections. First, the $\mathrm{AB}$ referred to the principle in dubio mitius to reject the idea that voluntary standards might bestow international obligations on WTO members; ${ }^{122}$ secondly, the recurring emphasis on members' freedom to choose their own level of protection cannot be assumed to operate only upwards; thirdly, the possibility that standards themselves are challenged (for inefficiency, see previous section, or for inadequate scientific basis) suggests that they do not impose a mandatory minimum level of protection. ${ }^{123}$ A last consideration should defuse the floor-hypothesis, based on a reading of the whole SPS Agreement. Interpreting articles 3(1) and 3(3) SPS so as to prohibit lower-than-standard measures would virtually nullify the effect of those provisions (such as articles 3(4) and 5(6) SPS) that allow developing

\footnotetext{
118 See supra, nn (102 to 104 and 106) for a sample of the available studies on this point. However, these sparse remarks have not been used against the 'hardening' narrative, as this article seeks to do.

$119 \mathrm{~J}$ Scott, The WTO Agreement on Sanitary and Phytosanitary Measures (OUP 2007) 261-266. 120 ibid 262. 121 ibid 263.

122 See Hormones (n 51) para 165, and the analysis supra (n 103).

123 Scott (n 119) 264.
}

\section{CAMBRIDGE JUURALS}


countries to base their trade choices also on their limited economic resources. $^{124}$

These considerations, as well as those analyzed above in this section, point to one direction. International standards are not binding in the WTO, not only because more stringent measures are acceptable, subject to certain requirements, but also because less stringent measures are permitted, and standards are not able to trigger a ratchet-up effect on domestic policies, at least de jure.

\section{A Counterfactual}

Is it possible that lower-than-standard national measures may in fact be successfully challenged under the TBT and SPS? Albeit residual, this hypothesis cannot be categorically excluded, and the very limited case-law available allows for no absolute certainty on this issue.

As seen above, regulations lessening the protection provided by relevant international standards might be deemed to violate articles 2(4) TBT and 3(1) SPS. This would hold true assuming that these regulations have some detrimental effect on trade, both to meet the letter of article 1(1) TBT and, more generally, to hypothesize a reasonable litigation scenario under the terms of article XXIII GATT, providing that the launch of a settlement mechanism follows the alleged nullification or impairment of some trade benefits.

First, it seems that the requirement that regulations 'be based on' relevant standards is more elastic downwards than upwards. As seen above, regulations 'based on' standards (articles 3(1) SPS and 2(4) TBT) do not require their complete incorporation, ${ }^{125}$ unlike measures 'conforming to' or 'in accordance with' them (articles 3(2) SPS and 2(5) TBT). Although the case-law has not yet clarified the scope and quality of such a divide, it has made clear that when compliance with the international standard can result in a violation of the domestic regulation, this latter cannot be deemed to be adopted 'on the basis' of the former. ${ }^{126}$

In the case of looser standards, in fact, it seems that such one-sense contradiction would not arise. ${ }^{127}$ Let us rehearse the Sardines example.

\footnotetext{
124 ibid 265-266. These conclusions are replicated and agreed upon in L Gruszczynski, Regulating Health and Environmental Risks under WTO Law (OUP 2010) 102-104. On the flexibility devices of TBT and SPS designed to accommodate developing countries' needs see G Mayeda, 'Developing Disharmony? The SPS and TBT Agreements and the Impact of Harmonization on Developing Countries' (2004) 7 J of Intl Economic L 737, $746 \mathrm{ff}$.

125 See Hormones (n 51) para 163. $\quad{ }^{126}$ See Sardines (n 48) para 248.

127 See S Charnovitz, 'The Supervision of Health and Biosafety Regulation by World Trade Rules' (2000) 13 Tulane Environmental LJ 271, 287, noting that looser regulations would not be illegal for the very fact that they deviate in peius from standards, since they would still be expected to meet the other requirements (scientific justification, non-discrimination, least-restrictiveness). We just note that not only is compliance with such requirements easier to achieve in the case of less stringent regulations (with the only possible exception of the alignment obligation under art 5(5) SPS), but - primarily-it seems unlikely that such regulations are ever challenged by foreign exporting countries, if only in that they could hardly entail any detrimental trade effect.
}

\section{CAMBRIDGE JDURNALS}


The Codex standard allowed the species Sardina sagax to be marketed as 'Peruvian sardines' whereas the EC measure prohibited using any 'sardines' denomination for fish other than the Sardina pilchardus. The contradiction is clear that, using the denomination 'Peruvian sardines' in keeping with the Codex, results in a violation of the EC norm.

If the EC norm, on the contrary, allowed the use of the unqualified 'sardines' denomination not only for the pilchardus species, but also for the sagax one, we would have the opposite scenario, and in the EC market, naming and labelling standards would be less stringent than required by the Codex. In this case, no contradiction in the above sense would arise, as compliance with the Codex would never result in the violation of the EC measure. ${ }^{128}$ Arguably, this would be precisely the case in which incomplete incorporation of the standards would not prevent the national regulations from being deemed 'based on' them, under article 2(4) TBT.

Moreover, it would be difficult to understand who would be worse off; at most, the disparate effect of a similar measure would be detrimental to Sardina pilchardus producers, who would lose the relative advantage given by the Codex standard, but this does not seem a compelling argument. In addition, the latest records of ongoing complaints and requests of consultations clearly show how States' concerns invariably relate to restrictive State practices, rather than instances of distorting liberalization lessening relevant standards. ${ }^{129}$

\footnotetext{
128 Compliance with the measure, instead, might result in a deviation from the Codex standards, but their voluntary nature would imply little consequence in case of violation, at least outside the Codex regime.

129 See, for instance, the table of cases and complaints included in the Fifteenth Annual Review of the Implementation and Operation of the TBT Agreement, prepared by the TBT Committee and published on 5 February 2010, document No G/TBT/28, and the detailed 'trade concerns' raised at the June and November 2009 sessions by the Member States (see the respective Minutes of each session in documents G/TBT/M/48 of 29 September 2009 and G/TBT/M/49 of 22 December 2009). The only concerns which do not squarely deal with the stringency of the standards deal with their unreasonableness. For instance, the EC expressed some concern on the possibility that Brazil introduced a verification procedure on imported health products based on requirements other than those already included in an ISO standard. The EC insists that these procedures be based on the ISO standards (see the Minutes of the November meeting, para 142) not so much because they are more lenient (in fact, it does not transpire that they are) but because, by their very divergence from the standards, they are unreasonably burdensome.

Likewise, in the SPS framework, concerns reflect the awareness that standards are likely to be used to foster trade more than health concerns. See, for instance, the debate about the possible adoption of a Codex standard setting the maximum residue of ractopamine in pork and swine feed. It is significant that those who push for the adoption of the Codex standard are indeed the States willing to market meat administered with ractopamine, whereas the EC and China, who had concerns about the harmfulness of this substance, appear reluctant to accelerate the standard-setting activity. Under a very candid cost-benefit perspective, it transpires that it is preferable for States that are relatively more concerned with health protection not to have the standard at all, than to have it used in the SPS system as an anti-regulation device enforceable by the DSB (see Summary of the Meeting of the SPS Committee of 28-29 October 2009, document G/SPS/R/56 of 28 January 2010 , particularly paras $141 \mathrm{ff}$.
}

\section{CAMBridge JUURNALS}


In light of this purported trade-inoffensiveness of international standards, then, it comes as no surprise that the majority of standard-related trade concerns, in fact, arise in connection with the proliferation of private standards (voluntarily set and applied by importers and retailers, and not reflected in State measures), that at once pierce the protection ceiling constituted by international standards, and escape the application of SPS and TBT disciplines, not being attributable to a Member State. ${ }^{130}$

It is not necessary here to investigate extreme cases where the protection accorded domestically was lowered to a reckless threshold (eg any fish meat can be marketed with the denomination 'sardines'; or no threshold whatsoever of growth hormone administration is established with respect to beef meat). Similar national measures would increase trade flows overall (possibly affecting the sales of products complying with higher standards), but their questionability would be less a matter of trade law than of responsible governmental policies and public order. ${ }^{131}$

\section{THE REGIME SHIFT}

In the previous part of this article, it was indicated that the purpose of ISO and Codex standard-setting systems is conceptually confused, which may serve to explain the apparent schizophrenia of the standards hypothesized above. With respect to the Codex, it seems clear that in the WTO regime the prevailing purpose of the standards is 'to guide and promote the elaboration and establishment of definitions and requirements for foods to assist in their harmonization and in doing so to facilitate international trade'. ${ }^{132}$ The same holds true with ISO standards; among the various purposes of the standardsetting activity, the only relevant one in the WTO appears to be that of granting to 'businesses using International Standards' market access to 'many more markets around the world'. ${ }^{133}$

\footnotetext{
130 See the Minutes of the June 2009 meeting of the TBT Committee (n 129), particularly para 326. On the issue of private regulation regimes and the WTO, see S Bernstein and E Hannah, 'NonState Global Standard Setting and The WTO: Legitimacy and the Need for Regulatory Space' (2008) $11 \mathrm{~J}$ of Intl Economic L 575; Vogel (n 17) 264-265.

${ }^{131}$ These measures would be challengeable under SPS and TBT to the extent that it is relatively easier for the complainant to show that, whatever the interest they are alleged to protect, less restrictive alternative measures are available. In this extreme case, however, it would be less a matter of protection than of mere unreasonableness and inefficiency of the policy adopted.

${ }^{132}$ See Codex General Principles, 'Purpose of the Codex Alimentarius,' available at $<\mathrm{http}: /$ www.fao.org/DOCREP/005/Y2200E/y2200e05.htm\#bm05>. See the statement of WTO DirectorGeneral Pascal Lamy: '[the SPS Agreement] was not primarily conceived with consumers in mind.' Address at the Assembly of Consumers Associations in Europe Conference (18-19 November 1999), available at <http://ec.europa.eu/dgs/health_consumer/library/speeches/ speech25_en.html $>$.

${ }^{133}$ See $<$ http://www.iso.org/iso/about/discovers-iso_who-standards-benefits.htm >.
}

\section{CAMBRIDGE JDURNALS}


Consider how the focus of the WTO differs from the UN endorsement of standards, contained in General Assembly Resolution 39/284:

39. Food. When formulating national policies and plans with regard to food, Governments should take into account the need of all consumers for food security and should support and, as far as possible, adopt standards from the Food and Agriculture Organization of the United Nations and the World Health Organization Codex Alimentarius or, in their absence, other generally accepted international food standards. ${ }^{134}$

The quality or health-related function of national policies, instead, is treated with relative indifference in WTO texts; ${ }^{135}$ it is not questioned when it is incorporated into recognized standards, and it is suspected to shield protectionist practices when standards are exceeded. ${ }^{136}$

International standards are not upgraded into WTO rules, if that is what is currently referred to by the 'hardening' rhetoric. They are simply used as a benchmark to discourage stringent national policies. The technical instructions that standards contain are extracted and used as a yardstick, as a fact whose only purpose is to flag the threshold over which WTO scrutiny becomes more severe: whatever soft normative effect standards had originally, it is not hardened, it is gone. ${ }^{137}$

The shift in function, supported by a shift in purpose, requires a re-run of the ANIME analysis provided above (A), and a tentative comparison with other standard regimes, as regards the due diligence defence (B) and the identification of third party beneficiaries or affected subjects $(C)$.

\footnotetext{
134 United Nations General Assembly Resolution A/RES/39/248 of 16 April 1985, mentioned in Henson and Humphrey (n 13) 23, emphasis added.

135 Wouters, Marx and Hachez (n 103) 14. See the remarks expressed above about the ambiguity of the SPS Preamble.

${ }^{136}$ In the TBT and SPS, national technical regulations are treated as NTB (non-tariff barriers), and can be reviewed to prevent national practices of 'regulatory protectionism'. See Buthe (n 3) 222; AO Sykes, 'Regulatory Protectionism and the Law of International Trade' (1999) 66 U of Chicago L Rev 1.

137 The possibility that legal elements are transformed when they are used in a different regime is a classic example of interplay between legal orders, see for instance how Santi Romano, L'ordinamento giuridico (Sansoni Firenze 1946) n 96bis described the possible ways in which one legal order (or part thereof) can be relevant to another legal order: '[i]t can disregard or refuse another order's existence; it can take another order into consideration, but providing it with a different nature than the one this latter would attribute to itself. Likewise, a legal order can equate another legal order to a mere fact, ignoring his legal nature, or acknowledge it as a legal system, but only to a certain extent and to certain effects, perhaps subject to the conditions that it deems opportune to impose' (emphasis added). Note that the use of standards as facts (ie, as static units of measurement) has little to do with the well known issue of the proof of foreign law (regarding the difficulties arising when the law of one order has to be proved and applied before a court of another legal system), which is generally summarized with the maxim that the proof of foreign law is proof of fact (see, for instance, A Miller, 'Federal Rule 44.1 and the 'Fact' Approach to Determining Foreign Law: Death Knell for Die-Hard Doctrine' (1967) 65 Michigan L Rev 613).
}

\section{CAMBRIDGE JOURNALS}




\section{A. New ANIME}

Since this new ANIME review is intended to account for the shift of purpose mentioned above, it is appropriate to examine in particular the phases from Implementation to Enforcement. Indeed, it is at the implementation phase that the purpose plays a material function, and affects the further course of the regulatory process. This does not mean that the WTO endorsement does not entail some changes in earlier phases ${ }^{138}$ (for instance, it is clear that States might have changed their approach when getting to choose among standard proposals, ${ }^{139}$ and that they have a different and stronger incentive to participate and shape the outcome of the process $)^{140}$. However, these changes would mainly affect the content of the standards adopted, an aspect that is relatively unimportant for this study. Moreover, at the risk of lapsing into over-simplistic statements, we shall treat Codex and ISO standards jointly, in light of the 'conceptual similarity' 141 of the WTO provisions that, respectively, regulate their function in the DSM.

\section{a) Implementation}

The shift in purpose ${ }^{142}$ that we have described requires a re-thinking of the implementation phase. Trade-related and harmonization concerns are satisfied by national authorities and regulators better than by single firms; indeed, the monitoring and enforcement phases in the WTO do not generally target firms' deviation from standards, but rather State failure to ensure a fair market

\footnotetext{
138 Shamir-Borer (n 31) 23.

139 Pauwelyn (n 51) 226: 'knowing that standards are no longer voluntary but at least partially enforceable at the WTO, countries may be wary to issue new standards'. See Victor (n 40) 931: 'the agenda and standards in the Codex are determined heavily by the SPS policies in the advanced industrialized countries'.

140 S Maljean-Dubois and É Etchelar, 'World Trade and International Normalisations: Codex Alimentarius' in K Byttebier and K Van der Borght (eds), WTO Obligations and Opportunities: Challenges of Implementation (Cameron May London 2007) 121, 141: 'By making the Codex adopt its point of view, a state of a group of states is (almost) totally sheltered from being sanctioned by the WTO'.

141 See Sardines (n 48) 275.

142 As for standards in the TBT, it is significant to note how the Russian-doll-like inextricable definition of standards betrays to some extent this shift (from common good to trade). Whereas the Agreement in itself is consistent in referring to standards as an element of trade facilitation, compare the text of a footnote with the definition of standards contained in the ISO/IEC Guide 2:2004 referred to by annex 1.2 to the TBT, whose definitions are, in turn, recalled by art 1(2) TBT: 'Standards should be based on the consolidated results of science, technology and experience, and aimed at the promotion of optimum community benefits' (emphasis added). In relation to the implementation of Codex standards, see Henson and Humphrey (n 13) 5, stressing that the implementation of standards is not compliance by firms, but rather adoption by States: 'Codex does not implement or assess conformity with the international standards, guidelines and recommendations it develops. Rather, implementation is dependent on adoption by Codex members, in whole or in part and formally or informally, and/or incorporation into the standards of other bodies, including private standards setters.'
}

\section{CAMBRIDGE JDURNALS}


treatment to foreign producers complying with standards. Implementation can be intuitively identified referring to the subsequent phases; a given activity certainly ranks as 'implementation' when the failure to perform it properly is subject to monitoring and potentially founds a claim. Since States (and State authorities) are the only subjects covered by SPS and TBT provisions, this re-allocation of the Implementing phase to State officials seems appropriate.

\section{b) Monitoring}

Monitoring of member countries' compliance seems to depend largely on the possibility of setting up trade disputes. ${ }^{143}$ Therefore, actors monitoring compliance with standards are export firms and exporting States, that is to say trade-affected parties. The SPS Committee has adopted a monitoring procedure on compliance with international standards, as required by article 12 SPS. However, it is pretty evident that the real object of the monitoring activity is the potential occurrence of trade effects connected with the standards. ${ }^{144}$

\section{c) Enforcement}

Enforcement is provided by the Dispute Settlement Mechanism of the WTO, triggered following the failure of amicable negotiations and the submission of a claim by a State. In case of violation, the panel or the $A B$ orders the losing State to bring the challenged measures into compliance; in our case, this means that the State must amend the regulatory measure challenged, either to make it consistent with the ISO or Codex standards, or in a way that allows the State to meet the further conditions of article 3(3) SPS or 2(5) TBT. In cases of continuous non-compliance, and subject to further judicial authorization and

143 Pereira (n 7) 1703.

144 See the wording of the SPS Committee decision revising the monitoring procedure established in 1997 (G/SPS/11/Rev.1 of 15 November 2004): '5. The international standards, guidelines or recommendations proposed by a Member to be monitored ... should be limited to those which have a major trade impact. The trade impact of an international standard, guideline or recommendation should be determined primarily on the basis of the extent to which Members use the standard (apply it to imports) and the frequency or severity of problems experienced in the trade of the goods covered by the standard'. See Joint FAO/WHO Food Standard Programme Codex Alimentarius Commission, Thirtieth Session Rome, Italy, 2-7 July 2007, Activities of the SPS Committee and Other Relevant WTO Activities from 2006 to the Present, Report by the WTO Secretariat: 'Monitoring the Use of International Standards 12. The procedure adopted by the SPS Committee to monitor the use of international standards invites countries to identify specific trade problems they have experienced due to the use or non-use of relevant international standards, guidelines or recommendations' (available at <ftp://ftp.fao.org/codex/CAC/CAC30/if30_05e. pdf $>$ ). See Naiki (n 98) 1274, noting that the procedure is not used substantively, and targets only standards with a major trade impact.

\section{CAMBRIDGE JUURALS}


instructions, ${ }^{145}$ the winning State can proceed to private enforcement, that is, it can suspend trade concessions agreed under the WTO Agreements vis-à-vis the counterparty. This typically results in the raising of tariffs against goods imported from the losing party, and States can be authorized to apply it to market segments different from that in which the defendant adopted (and keeps in force) the discriminatory regulation.

\begin{tabular}{|c|c|c|}
\hline Phases & Original ANIME & WTO-related ANIME \\
\hline Agenda Setting & \multicolumn{2}{|c|}{$\begin{array}{l}\text { Members to Codex and ISO (State authorities and private sector, } \\
\text { both producers and consumers) }\end{array}$} \\
\hline Negotiation & \multicolumn{2}{|c|}{ Members to Codex and ISO } \\
\hline Implementation & Companies (private subjects) & $\begin{array}{l}\text { Trade regulators } \\
\text { (public authorities) }\end{array}$ \\
\hline Monitoring & $\begin{array}{l}\text { Private sector, consumers, hybrid } \\
\text { certification models }\end{array}$ & $\begin{array}{l}\text { Exporting states } \\
\text { (on behalf of exporting } \\
\text { companies); SPS and } \\
\text { TBT Committees }\end{array}$ \\
\hline Enforcement & $\begin{array}{l}\text { Market actors (consumers, retailers, } \\
\text { certification agencies); State officials } \\
\text { (regulatory authorities, judicial actors) }\end{array}$ & $\begin{array}{l}\text { DSB bodies; States } \\
\text { winning a DSM } \\
\text { dispute }\end{array}$ \\
\hline
\end{tabular}

\section{B. The Due Diligence Defence, and the Identification of Beneficiaries}

From the outset, the inclusion of standards in the WTO framework simply amounts to a codified due diligence defence. States basing their technical regulations on international standards will come before the WTO quasijudicial bodies with clean hands. This presumption of good faith provided by the TBT and SPS, however, has nothing to do with the due diligence devices that are typically related to voluntary standards in the context of court litigation.

By means of a simple comparison it may be demonstrated how the shift in purpose is also reflected in the actual 'adjudicability' of standards (their function in litigation); notwithstanding all the 'hardening' claims, ISO and Codex standards are voluntary, both as such and in the WTO system. Therefore, the way in which judges apply them to resolve a dispute is a very telling benchmark of their inner telos; when courts take them into account they do not do so under precise rules of liability, but they abstract from the standards a combination of elements (an evidence of good faith, a model of the duty of

\footnotetext{
${ }^{145}$ Under DSU art 21(5).
}

\section{CAMBridge JOURNALS}


care that may be exacted, the objective of protecting public interest values) that may inform the application of general principles of liability.

In general, voluntary standards are not directly enforceable, that is, a violation does not automatically entail an actionable claim by the affected party. However, courts are likely to take into account voluntary standards and give them weight in two senses: compliance with standards can support a successful due diligence defence (especially if they are commonly agreed upon), and non-compliance with voluntary standards may support the determination of a breach of the duty of care. ${ }^{146}$

For instance, in the product safety framework, compliance with voluntary standards frees producers from the burden of proving that their products are safe, whereas in case of non compliance they will have to discharge the relative burden of proof. ${ }^{147}$ This is the typical design of the due diligence defence; it does not entail an automatic equivalence between non-compliance and liability (and vice versa), but displaces the burden of the proof away from the defendant who has adopted more public-interest concerned measures (more precisely, it does so by increasing the burden on the plaintiff, who is called on to provide the more difficult evidence of producer's negligence despite compliance with the standards).

In contrast, compliance with the standards in WTO disputes, as noted above, is mainly a defence against the claim of trade-restrictiveness. In other words, it is a litigation mechanism conceived to induce importing States not to select autonomously the least trade-restrictive technical measures, but rather to use

\footnotetext{
146 See the Arbor Drugs case (Baker v Arbor Drugs, Inc., 544 NW2d 727, 731; (Mich Ct App) 1996) described in Chan (n 30) 1147-1148: '[the] defendant voluntarily assumed a duty of care when it implemented [a ISO 9000 certified software system for the management of drug prescriptions] and then advertised that this system would detect harmful drug interactions for its customers' (emphasis added). This example is particularly significant because it displays how ISO standards can be interpreted before a non-WTO court, and serve as foundation of a due diligence defence that has nothing to do with the presumption of WTO-compliance provided in the TBT Agreement. ibid 1153-1160, see how additional self-failure assessment requirements (Failure Mode and Effects Analysis) enshrined in the QS 9000 standards for designers and manufacturers (the US version of ISO 9000) could end by substantiating plaintiffs' claims for product liability: 'FMEAs inherently provide all the basic ammunition to a plaintiff to establish a design [or manufacturing] defect, [or a] a marketing defect or failure to warn.' See also Bruno and Pynnonen (n 39) 1080: 'Even if ISO 9000 adoption statements are not interpreted to give rise to independent obligations, they may be sufficient under the UCC to render the seller's warranty disclaimers unreasonable, and thus ineffective'.

147 For an appraisal of the relationship between standards and liability in the area of product safety, see Cafaggi (n 17) 10. See for instance Preamble, point no 14, arts 3(2) and 3(3) of the Product Safety EC Directive 2001/95/EC of the European Parliament and of the Council of 3 December 2001, OJ L 11, 15.1.2002, p 4-17, setting forth a presumption of safety for the products conforming to national standards transposing European safety standards. This is a telling example of the 'New Approach' adopted by the EU, whereby the Commission sets the general requirements for products and services, leaving it to voluntary standards the task of providing detailed specifics. In this framework, the main standardization body is the CEN (Comité Européen de Normalisation), an organization comprised of all EU members national standardization bodies. See J Morrison and N Roht Arriaza, 'Private and Quasi-private Standard Setting' in D Bodansky and others (eds), Oxford Handbook of International Environmental Law (OUP 2007) 498, 520.
}

\section{CAMBridge JUURNALS}


standards as guidance, and enjoy the safe haven granted thereby. This incentive is clearly beneficial to exporters' interests, because it aims at preventing States from adopting de facto discriminatory trade measures.

This distinction gives rise to a particular phenomenon of unintended (even perverse) consequences; whereas the obvious beneficiaries of Codex and ISO standards are the consumers (who would benefit from enhanced quality and safety of the purchased goods $)^{148}$ the very same standards, when used in the WTO litigation setting, are used to protect exporting companies' interests. ${ }^{149}$ To put it differently, even conceding that international standards reach the status of hard law in the WTO framework, they would do so solely in connection with the protection of free trade, and have no increased effectiveness as regards their original purpose (the protection of consumers). ${ }^{150}$

In keeping with the remarks above, it is relevant to consider how the lack of a direct effect of WTO law influences the identification of the regulated subjects and of the beneficiaries in the Codex and the ISO regimes. As anticipated, this yields counterintuitive results; the incorporation into the WTO framework results in a shift of (third-party) benefits from the consumer to the manufacturers/producers (the exporting sector), and makes it harder to compare the regimes with other analogous consumer/workers/environment protection schemes. Consumers are arguably worse off, because WTO rules set a disincentive to adopt overly stringent standards; ${ }^{151}$ however, private regulation can make good the deficiencies, using an enhanced quality standard as a mechanism to enhance market share. Besides a certain threshold, in other words, the segmentation of supply according to quality standards is becoming privatized; producers and providers use compliance with higher stringent

\footnotetext{
148 Bruno and Pynnonen (n 39) 1076: 'The ISO 9000 series is a set of standardized procedures and principles that sellers can adopt to ensure customer satisfaction. ... Customer satisfaction, both with the product and with the system developed to create the product, is the ultimate goal'.

149 This is somewhat different from the EC approach to technical standardization. Although many of the principles underpinning this 'new approach to technical harmonisation' (see at $<$ http:// europa.eu/legislation_summaries/internal_market/single_market_for_goods/technical_harmonisation/ 121001a_en.htm >) recall those laid down in the TBT and professed by the TBT Committee, yet compliance with the standards is not a mere defence against the charge of trade-restrictiveness, but creates a presumption of good faith in that it creates a link between the technical regulation and the 'essential requirements' and public interest it pursues. See Council Resolution of 7 May 1985 on a new approach to technical harmonization and standards (Council Resolution (85/C 136/01), Official Journal C 136 of 4 June 1985; referring to the Council Directive 83/189/EEC of 28 March 1983 laying down a procedure for the provision of information in the field of technical standards and regulations, Official Journal L 109 of 26 April 1983.

150 See SA Shapiro, 'International Trade Agreements, Regulatory Protection, and Public Accountability' (2002) 54 Administrative L Rev 435, 451: 'when international standard-setting organizations issue standards that are less stringent than similar regulations in the United States, it opens the door for other countries to challenge more stringent American regulations.'

151 See JH Mathis, 'The WTO Agreement on Technical Barriers to Trade (TBT) Interaction with international standards and implications for consumers' in K Dawar (n 33) 105, 124: 'From a national consumer perspective, it seems that the substance question turns upon whether a standard is posing as a floor or as a ceiling.' To the extent that the ceiling-argument has been proved, above, it follows that consumers are indeed worse off.
}

\section{CAMBRIDGE JOURNALS}


standards (and the publicity thereof, eg through labelling) as leverage to meet consumers' preferences.

It is not clear whether, in the end, consumers are definitely worse off; private standards might very well serve the purpose. Nevertheless, some issues are likely to arise in the largely uncharted scenario of private standards; the costs of compliance with higher voluntary standards is often transferred onto customers/consumers, and could be high enough to discourage them from paying the additional cost, or the producers from imposing it in the first place. In other words, where neither public policy nor market feasibility seems to back the application of higher protection standards, they will simply be disregarded. In any event, it appears that (as reflected in the genuine concerns expressed by the States in the TBT and SPS Committee sessions) if any standards are actually used to raise the level of protection to the detriment of market flows, these are private standards, not international ones.

\section{CONCLUSION}

It is important to recall the central purpose of this article, by clarifying what is not argued here. First of all, this contribution does not claim that international standardization regimes are ineffective in providing better protection of the public good ${ }^{152}$ and regulatory harmonization, or that voluntary standards do not get incorporated in hard law instruments (for instance, in national binding standards ${ }^{153}$ ). Nor does it claim that the WTO system necessarily triggers a trend of downward harmonization, ${ }^{154}$ though it is fair to note that the stricter requirements that the TBT and SPS impose on national regulators to justify higher protection measures has resulted in the WTO DSB striking down some SPS and TBT measures exceeding international standards, and that the requirement to promote an overall alignment of national regulations, especially in the SPS area, might down-level the field rather than the opposite. ${ }^{155}$

This article's main purpose was to scrutinize the commonplace view of the hardening of standards through WTO endorsement, and show that the system of presumptions established in the TBT and SPS uses international standards more as a ceiling than as a floor benchmark of protection, as a codified and agreed yardstick for least trade-restrictive measures. ${ }^{156}$ It follows that the

\footnotetext{
152 See Henson and Humphrey (n 13), noting that the slow process guided by WTO case law would be ineffective in any event in influencing the regulatory regime timely.

${ }^{153}$ For instance, by including a reference to the standards in government procurement instructions, see eg Chan (n 30) 1216: 'the U.S. Federal Acquisition Regulations specify ISO 9000 and QS-9000 as examples of quality standards that may be required for compliance with higherlevel contract quality requirements'. $\quad{ }^{154}$ Victor (n 40) 920

155 ibid (2000) 924. Charnovitz (n 127) 284-285; see also WTO Committee on Sanitary and Phytosanitary Measures, Proposed Guidelines to Further the Practical Implementation of Article 5.5, G/SPS/W/104, para A.4 (20 March 2000).

156 Wirth (n 37) 96: 'operating through the TBT Agreement, non-binding ISO standards may acquire international legal significance, may be transformed from minimum standards of
}

\section{CAMBridge JUURNALS}


nature of standards - so far as their limited role in the WTO regime is concerned - is distorted, as they are relevant in the international trade legal system as a fact, not as norms contributing to the improvement of food-safety or product-quality protection.

Whereas this conclusion is the result of an analysis that focused prevalently on the WTO side of this regime interaction, we have followed in parallel the evolution of the standardization regime. A static breakdown of the regulatory process of international standardization allowed us to isolate which phases and which actors are affected by WTO absorption, and most importantly to describe with reasonable approximation the purpose shift that standards go through by virtue of their use by DSM bodies. The only junction point between the standards as such and their WTO double is their function of minimum compromise; the stress is on their minimum protection in the standardization field, ${ }^{157}$ while it is on their minimum distortion (least trade-restrictiveness) in the WTO area. ${ }^{158}$ In combining the two, standards survive the migration between the regimes, because they correspond to the area of overlap between the two epistemic orders, they represent the greatest common factor between trade values and those interests that originally triggered their adoption. The existence of this common core, at least, demonstrates that even in the WTO regime trade and non-trade interests are not relatively prime to each other, as they share a substantive (albeit mimimal) content.

performance into regulatory ceilings from which governments must justify departure in terms of greater rigor.'

157 Roht-Arriaza (n 37) 510, describing ISO practices: 'the global standard serves only as a floor.'

${ }^{158}$ Staiger and Sykes (n 89) 40.

\section{CAMBRIDGe JOURNALS}

